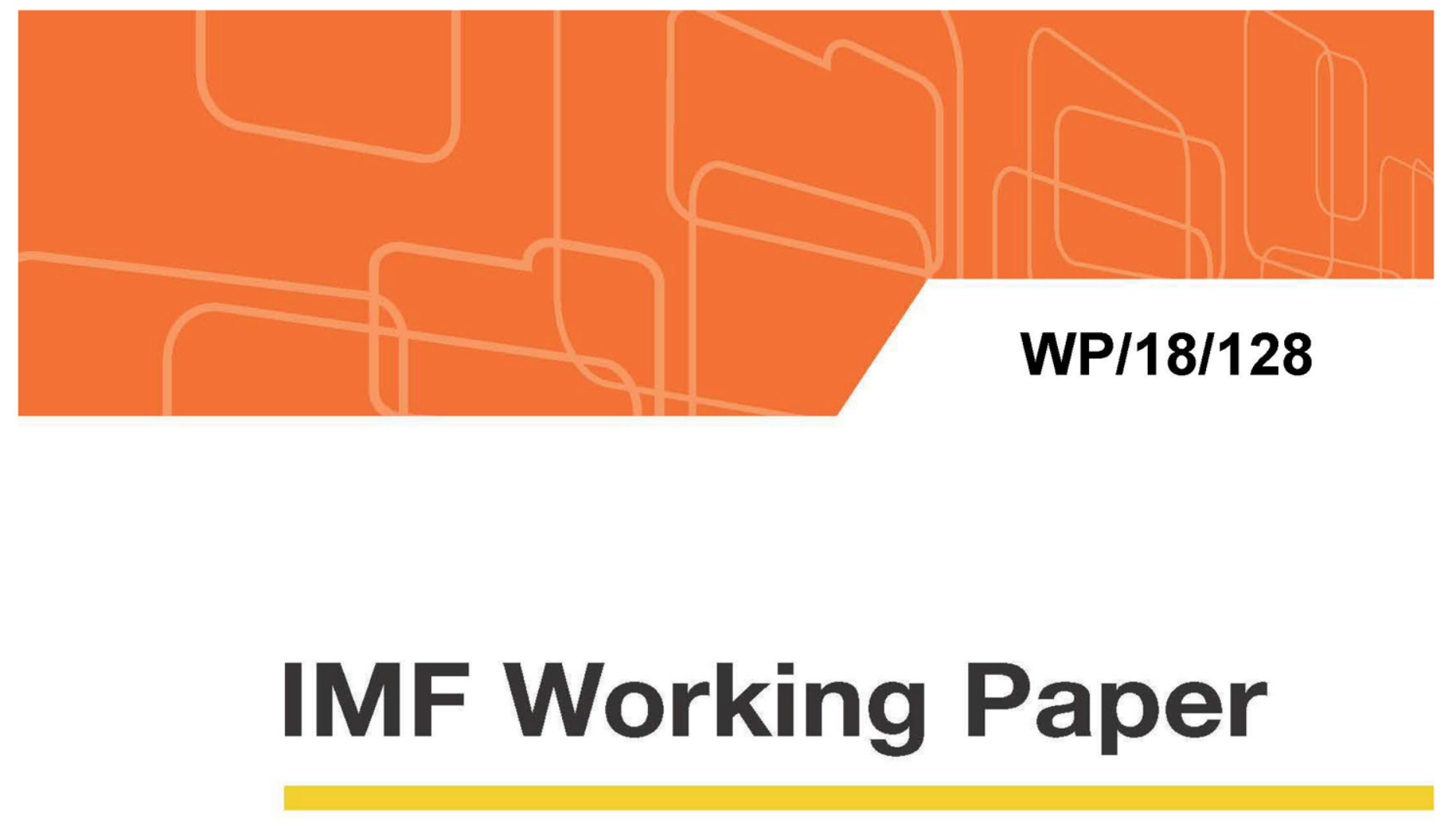

\title{
The U.S. Personal Saving Rate
}

By S. Ouliaris and C. Rochon

IMF Working Papers describe research in progress by the author(s) and are published to elicit comments and to encourage debate. The views expressed in IMF Working Papers are those of the author(s) and do not necessarily represent the views of the IMF, its Executive Board, or IMF management. 


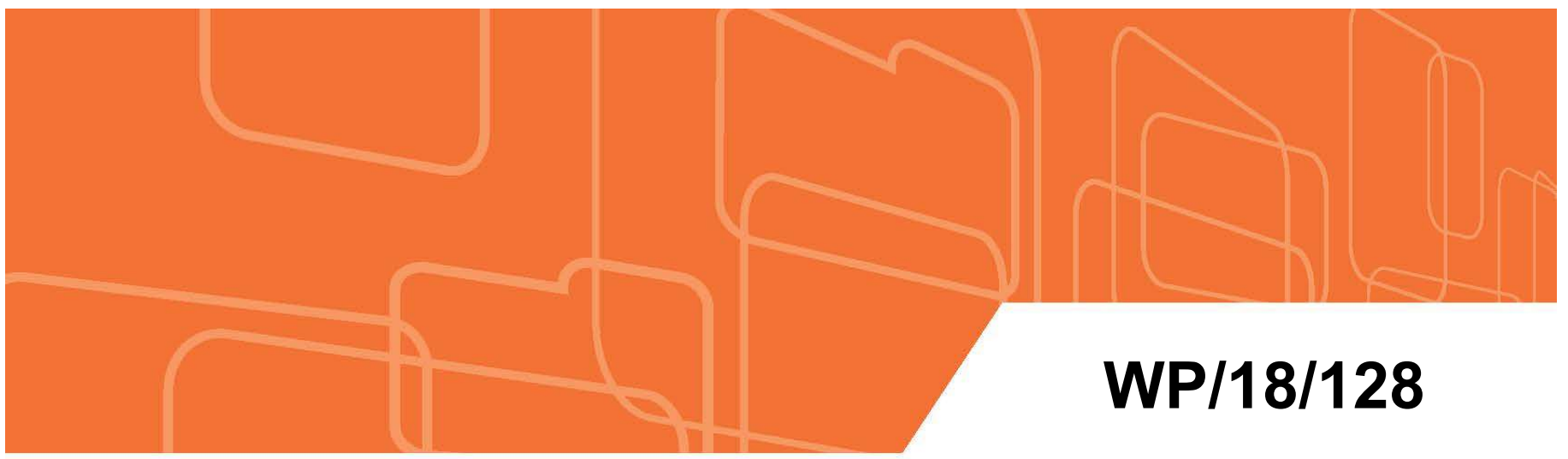

\section{IMF Working Paper}

\section{The U.S. Personal Saving Rate}

By S. Ouliaris and C. Rochon

IMF Working Papers describe research in progress by the author(s) and are published to elicit comments and to encourage debate. The views expressed in IMF Working Papers are those of the author(s) and do not necessarily represent the views of the IMF, its Executive Board, or IMF management.

I N T E R N A T I O N A L M O N E T A R Y F U N D 


\title{
IMF Working Paper
}

Western Hemisphere Department

The U.S. Personal Saving Rate ${ }^{1}$

Prepared by S. Ouliaris and C. Rochon

Authorized for distribution by Nigel Chalk

June 2018

\section{IMF Working Papers describe research in progress by the author(s) and are published to elicit comments and to encourage debate. The views expressed in IMF Working Papers are those of the author(s) and do not necessarily represent the views of the IMF, its Executive Board, or IMF management.}

\begin{abstract}
This paper develops a time series model for aggregate consumption to predict the U.S. personal saving rate. It then uses the model to test whether there has been a structural break in consumption behavior because of the 2008 financial crisis. Before the crisis, the personal saving rate was trending downwards. However, in 2008 there was a significant rise in the saving rate that continued until the end of 2012, suggesting a permanent change in household behavior. To assess this issue formally, the unknown parameters of the model are estimated using data for 1961Q1-2007Q4, a period which precedes the crisis. The model is then used to predict the saving rate from 2008Q1 onwards and to assess whether the rise in the saving rate after 2008 was due to sizable, but transitory, income/wealth shocks or to changes in the underlying elasticities between saving and its determinants (hence structural). The statistical evidence suggests there was no structural break in the household saving behavior, implying that the rise in the saving rate during 2008-2012 was caused by the negative shocks to income, employment and wealth. This result explains why the saving rate resumed its decline in 2013, as real disposable income, employment and net worth recovered. Assuming that the real growth in these determinants remains strong, the estimated model predicts continued negative pressures on the current account deficit and further external imbalances attributable to the U.S. household sector.
\end{abstract}

JEL Classification Numbers: D12, D14, D15, E21, E27

Keywords: consumption behavior, personal saving rate, vector error-correction model, structural break.

Authors E-Mail Addresses: sam.ouliaris@gmail.com; crochon@imf.org

\footnotetext{
${ }^{1}$ The paper has benefitted from comments from IMF staff in RES and WHD.
} 
II. DATA AND EMPIRICAL APPROACH__________ $\underline{9}$

III. FORECASTING PERFORMANCE OF THE BASELINE MODEL _____ _ $\underline{\mathbf{2 2}}$

IV. CONCLUDING REMARKS______

V. REFERENCES ____

APPENDIX _______________ $\underline{29}$

FIGURES

Figure 1. Actual and Smoothed Personal Saving Rate, 1961Q1-2017Q4_____ 4

Figure 2. Current Account Balance and Sources of Change, 2012-2017___ $\underline{6}$

Figure 3. Real Consumption, Real Disposable Income and Real Net Worth, 2006Q1-

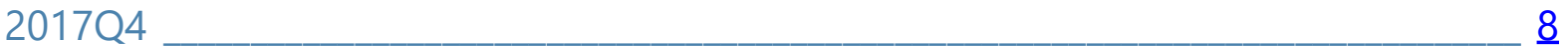

Figure 4. Historical Decomposition of Real Net Worth, Real Disposable Income and Real Consumption

Figure 5 Dynamic Simulation: Actual, Predicted and Smoothed Saving Rate, 2008Q1-

2017Q4

Figure 6: Dynamic Predictions for the Endogenous Variables, 2008Q1-2017Q4 __ 17

Figure 7: Saving Rate Fan Chart (Dynamic Simulation, 90 Percent Band), 2008Q1-2017Q4

Figure 8: Static Simulation: Actual, Predicted and Smoothed Saving Rate, 2008Q12017Q4 19

Figure 9: Static Predictions for the Endogenous Variables, 2008Q1-2017Q4___ 20

Figure 10: Saving Rate Fan Chart (Static Simulation, 90 Percent Band), 2008Q1-2017Q4

Figure 11: Actual and Predicted Saving Rate, 2017Q1-2017Q4 21

Figure 12: Out-of-Sample Predictions for the Saving Rate: 2018Q1-2019Q4 $\underline{23}$ Figure 13: Predictions with a Trend term in the Long-Run Model, 2008Q1-2017Q4 29 Figure 14: Fan Charts for the Saving Rate with Trend, 2008Q1-2017Q4 $\underline{30}$ Figure 15: Dynamic Predictions, Shorter Sample, 2002Q1-2017Q4____ 31 Figure 16: Fan Charts for the Saving Rate: 2002Q1-2017Q4_____ 31 Figure 17: Dynamic Prediction: Alternative Identification, 2008Q1-2017Q4____ $\underline{32}$ Figure 18: Fan Charts for the Saving Rate: Alternative Identification 32 


\section{TABLES}

Table 1. Unit Root Analysis, Augmented Dickey-Fuller Tests, 1961Q1-2007Q4 __

Table 2. Johansen Test Results ___ 11

Table 3. Baseline VECM Model____ 12

Table 4. VECM Parameter Estimates___ 14

Table 5: Multiple-Point Break Tests: 2008Q1-2017Q4____ 19

Table 6: Effect of Each Variable on the Predicted Saving Rate, 2008Q1-2009Q2 __ 22

Table 7: Multiple-Point Break Tests: Trend, 2008Q1-2017Q4___ $\underline{30}$

Table 8: Multiple-Point Break Tests: Shorter Sample, 2002Q1-2017Q4____ $\frac{31}{33}$

Table 9: Multiple-Point Break Tests: Alternative Identification, 2008Q1-2017Q4___ $\underline{33}$ 


\section{INTRODUCTION AND SUMMARY}

Following the 2008 financial crisis, there was broad support in the U.S. for measures to restore growth through expansionary monetary and fiscal measures and for strengthening the resilience of the financial sector. Moreover, the failure to anticipate the timing and severity of the crisis led many observers to ask whether the standard macroeconomic relationships used to produce forecasts omitted key macro-financial variables. They also questioned whether these relationships would remain useful after the crisis given the likely permanent changes in household and corporate behavior due to the crisis. Years later, the implications of the crisis on the standard macroeconomic relationships remain unclear. The aim of this paper is to shed some light on this issue in the case of the U.S. personal saving rate.

From 1975 to 2007 , there was a clear downward trend in the personal saving rate, which ended soon after the onset of the financial crisis in 2008 (Figure 1). There was a significant rise in the saving rate during 2008-2012, reflecting (possibly) the increased economic uncertainty associated with the financial crisis and the subsequent balance sheet restructuring and deleveraging by households. The saving rate resumed its decline around 2013 and now appears to be returning to its pre-2008 level.

Figure 1. Actual and Smoothed Personal Saving Rate, 1961Q1-2017Q4

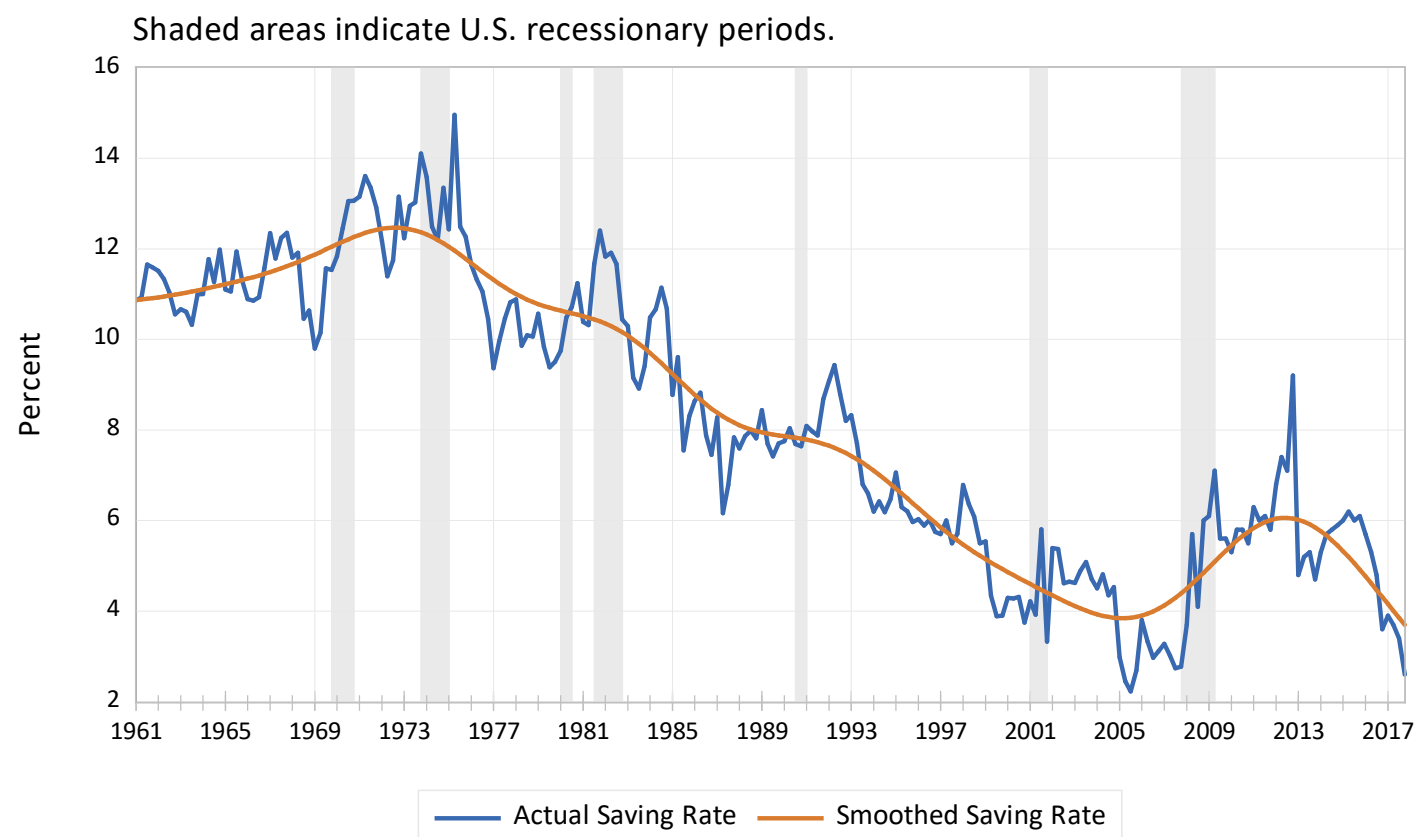

There is a lack of consensus on what caused these major swings in the saving rate, and whether they reflect structural (i.e., permanent) changes in the household sectors' saving behavior. $^{2}$

\footnotetext{
${ }^{2}$ See Caroll et al (2012); Lee et al (2010).
} 
This issue has implications for the outlook for U.S. consumption and GDP growth, financial market stability, and external imbalances. Understanding the fundamental determinants of the saving rate will help assess whether the gap between investment and saving has become more persistent because of changes in the long-run propensities to save and invest, and to inform discussions on the behavior of the current account and the potential for larger external imbalances.

To elaborate, Figure 2 shows the levels of the current account, gross saving and investment during 2012-2017, and the changes in these variables for 2013-2017. The changes in gross saving and investment are divided into private and public categories. In 2016, gross saving declined, mostly because of the decline in personal and public saving. Gross investment also fell because of a decline in private investment. Overall, the current account in 2016 worsened slightly, but the fall was reduced by the increase in private saving (excluding personal).

The increase in the current account deficit during 2017 can be attributed to the decline in personal saving and the increase in gross investment (both public and private), which in terms of their effect on the current account were offset by the increase in private saving (excluding personal).

These observations about the recent movements in the current account could not be drawn without a decomposition of savings into its components. The determinants of savings and investments therefore hold valuable information on the fundamental drivers of the current account. Given the importance of the personal saving component, this paper will focus on the behavioral characteristics of personal saving. ${ }^{3}$

To study personal savings, the paper develops a multi-equation, time-series model for aggregate consumption. The unknown parameters of the model are estimated using data until 2007Q4, which was chosen because it precedes the onset of the financial crisis. The estimated model is then used to predict consumption (and the saving rate) during 2008Q1 2017Q4 and to formally assess whether the rise in the saving rate is due to sizable, but transitory, income/wealth shocks or to changes in the underlying elasticities between consumption and its determinants (hence structural). The model is also used to conduct multiple-point structural break tests and generate out-of-sample forecasts for the saving rate for 2017Q1-2017Q4. By so doing, the paper sheds light on whether there has been a structural break in personal consumption behavior (and hence the saving rate) after 2007Q4.

\footnotetext{
${ }^{3}$ Caroll et al (2012) also focus on the determinants of the saving rate. They find that uncertainty effects (as measured by the expected unemployment rate), net wealth and credit availability are the main factors driving the saving rate.
} 
Figure 2. Current Account Balance and Sources of Change, 2012-2017

Current Account Balance, Gross Saving and Investment, Billions of US\$, 2012-2017

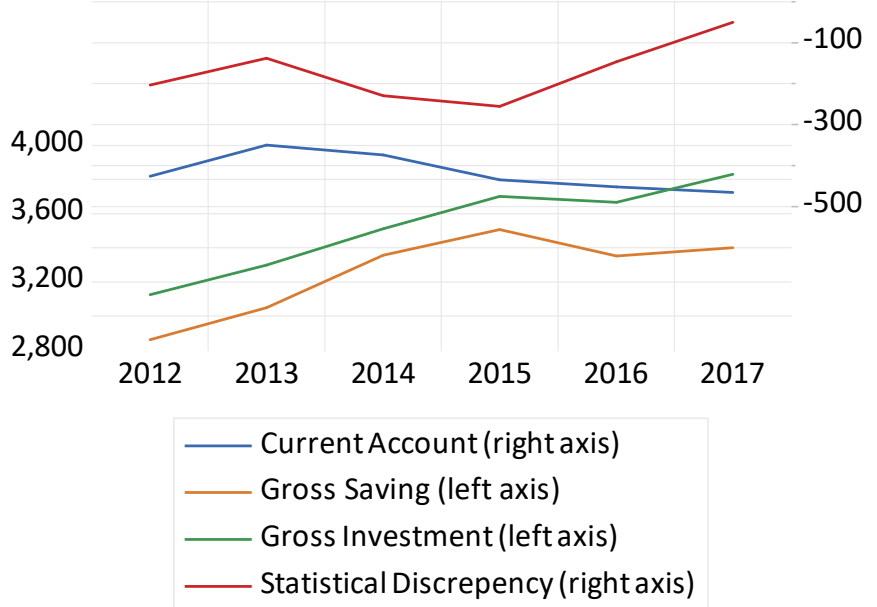

Changes in Gross Saving and its Components, Billions of Dollars, 2013-2017

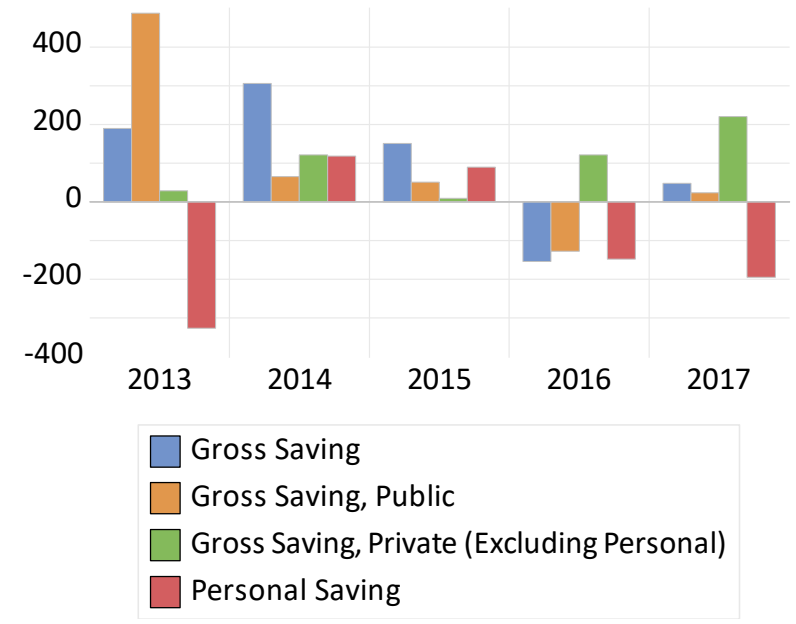

Change in the Current Account, Billions of Dollars, 2013-2017

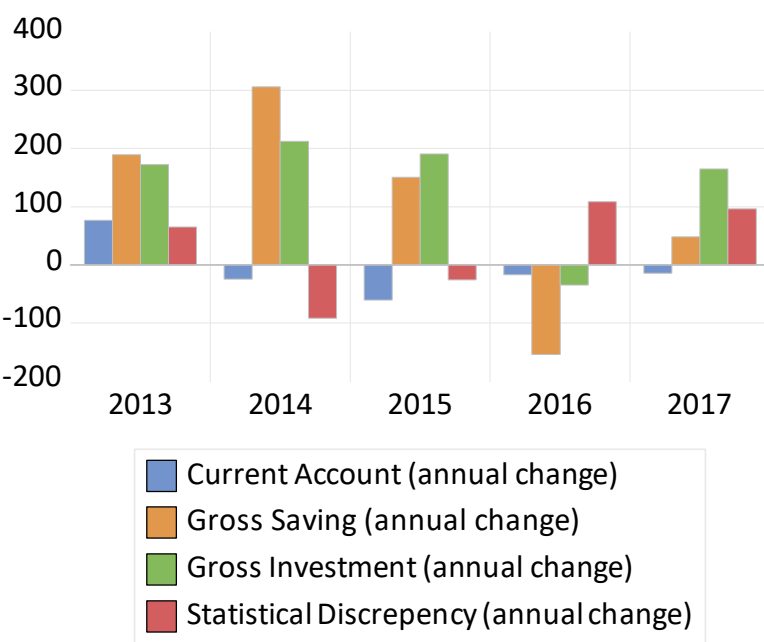

Changes in Gross Investment and its Components, Billions, 2013-2017

$$
250
$$

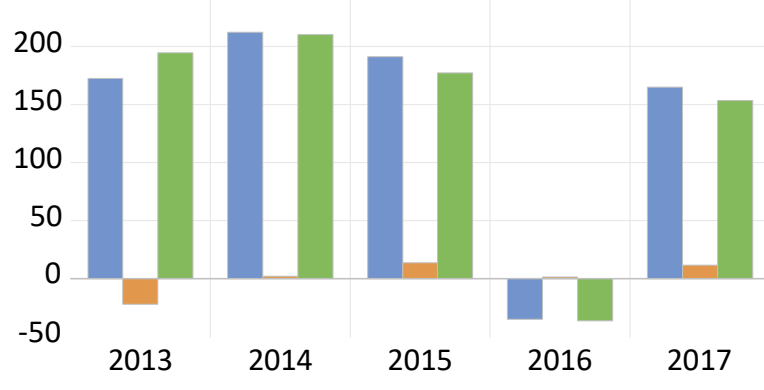


The data used for this analysis is National Income and Product Accounts (NIPA, quarterly) data, spanning 1961Q1 to 2017Q4. ${ }^{4}$ The variables of interest include real consumption, real disposable income, real household net worth, the dependency ratio, the real interest rate, the unemployment rate, a household confidence index, and the VIX, which acts as a proxy for financial market volatility.

Figure 3 shows the actual path of real consumption, real disposable income, and real household net worth over the period 2006-2017, as well as their annualized quarterly growth rates. During the crisis years, the marked decline in consumption can be associated with a very pronounced decline in real net worth, and weak and volatile growth in real disposable income. The growth of real disposable income decreased and was partly negative during that period. The model developed in the paper will validate these observations and show that there was no structural break in the household consumption behavior after 2007Q4. We find that the personal saving rate reflected the shocks to income and wealth during that period.

The paper is organized as follows. The next section presents the data and empirical approach, while section 3 discusses the forecasting performance of the model. Section 4 offers some concluding remarks. The appendix presents some robustness exercises.

\footnotetext{
${ }^{4}$ The data was released March 29, 2018. See https://bea.gov/newsreleases/national/pi/2018/pi0218.htm.
} 
Figure 3. Real Consumption, Real Disposable Income and Real Net Worth, 2006Q1-2017Q4
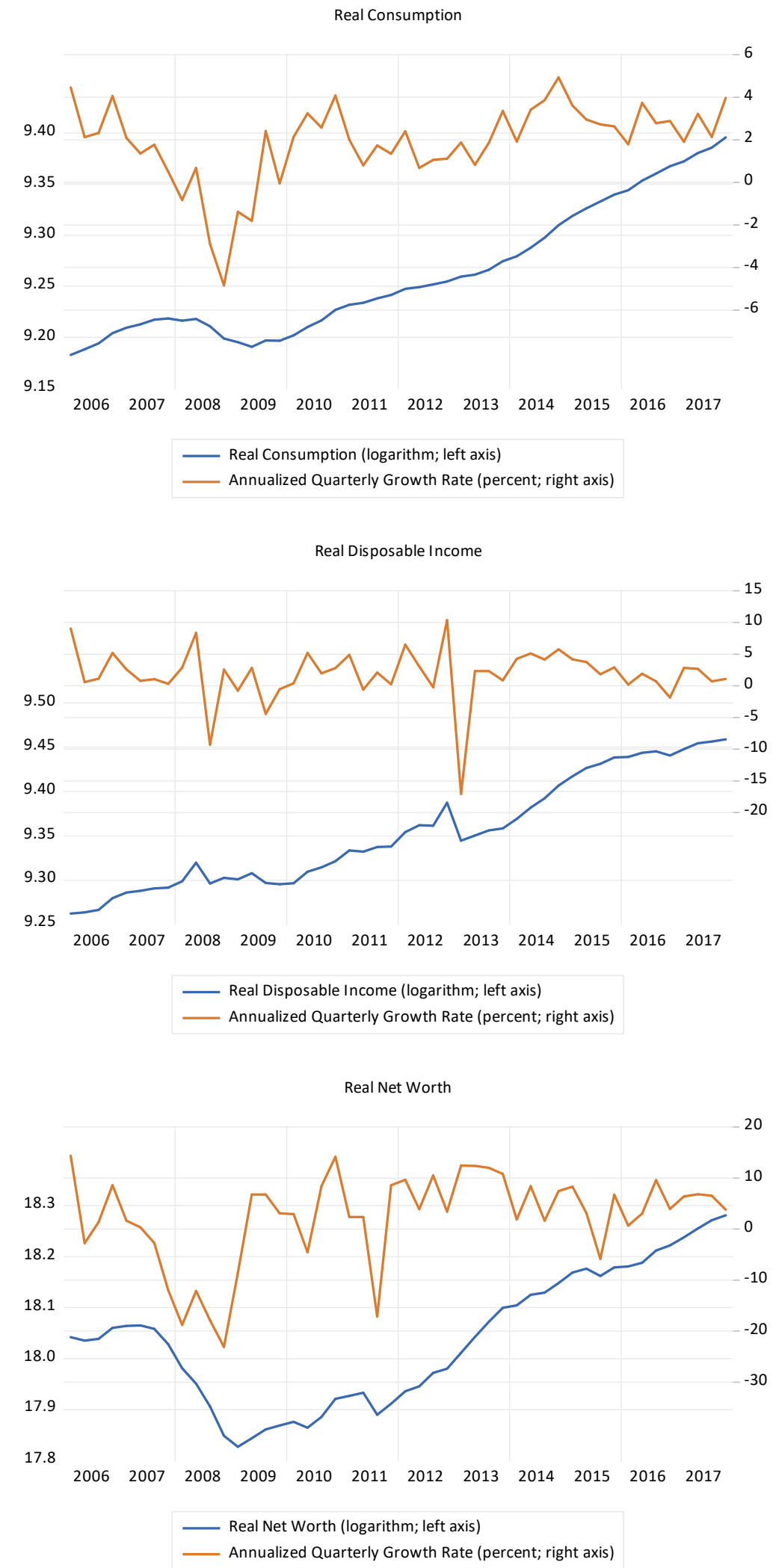

CInternational Monetary Fund. Not for Redistribution 


\section{DATA AND EMPIRICAl APPROACH}

The key variables used in the long-run real consumption equation are: real consumption (rc), real disposable income (rdy), real household net worth (rnw), the dependency ratio (dep_ratio), and the real federal funds rate (r_fed_rate)

The long-run real consumption equation, which seeks to explain the long-term path of real consumption, is modeled as follows:

$$
\ln \left(r c_{t}\right)=\beta_{0}+\beta_{1} \ln \left(r d y_{t}\right)+\beta_{2} \ln \left(r n w_{t}\right)+\beta_{3} r_{-} \text {fed_rate } e_{t}+\beta_{4} \ln \left(d e p_{-} r a t i o\right)+\varepsilon_{t}
$$

The choice of explanatory variables is driven by widely accepted theories for personal consumption expenditure. First, the Permanent Income Hypothesis $(\mathrm{PIH})^{5}$ and wealth effects explanations for consumption support the use of real disposable income and real net wealth as determinants of long-run consumption expenditure. Both should have positive elasticities. ${ }^{6}$ Secondly, inter-temporal substitution arguments support the inclusion of the real interest rate (proxied by the real federal funds rate) in this equation, ${ }^{7}$ while the life-cycle hypothesis of consumption supports adding the dependency ratio. ${ }^{8}$ The relationship between real consumption and the real federal funds rate is theoretically indeterminate, while that between real consumption and the dependency ratio, either directly or indirectly through negative effects on real wealth, is expected to be negative.

Equation (1.1) is a long-run model of consumption without any short-run dynamics. To address this issue, we study the short-run dynamics using a multi-equation error-correction model (VECM) to predict actual consumption and the personal saving rate. The personal saving rate will be derived from the VECM using the standard NIPA identity for saving, namely:

$$
\text { saving_rate }=100 *\left(r d y-\left(r c+\left(\left(\text { gov_transfers }+i_{-} \text {payments }\right) / y_{-} \text {deflator }\right)\right)\right) / r d y
$$

where government transfers to the household sector (gov_transfers), interest payments (i_payments) and the income deflator (y_deflator) are treated as exogenous variables. ${ }^{9}$

\footnotetext{
${ }^{5}$ Caroll (1997).

${ }^{6}$ Lettau and Ludvigson (2004); Maki and Palumbo (2001). Note that in the PIH, real disposable income is decomposed into a permanent and a transitory component, and the marginal propensity to consume from transitory income is assumed to be zero. For a formal test of this hypothesis, see Corbae, Ouliaris and Phillips (1994).

${ }^{7}$ Replacing the real Fed Fund rate with the 10-year yield on bonds does not change the qualitative results. Epstein and Zin (1991).

${ }^{8}$ Ando et al (1963), Cagetti (2003), Gourinchas and Parker (2002).

${ }^{9}$ Real government transfers and interest payments represent a small proportion of the saving rate. The empirical analysis that follows holds under the assumption that these variables are zero.
} 
Our analysis is based on the following idea. If the baseline empirical model-estimated using only data that preceded the onset of the financial crisis-can satisfactorily predict the observed saving rate during 2008Q1-2017Q4, this provides statistical evidence that the financial crisis did not change household saving behavior permanently. We also assess the model by conducting a more focused out-of-sample forecasting exercise for the 2017Q1-2017Q4 period.

We now determine the statistical properties of the data. Unit root analysis for the period 1961Q1-2007Q4 using Augmented Dickey-Fuller (ADF) statistics suggests that all the time series variables in the long-run regression (equation 1.1) have a unit root (i.e., are nonstationary) (Table 1).

Table 1. Unit Root Analysis, Augmented Dickey-Fuller Tests, 1961Q1-2007Q4

\begin{tabular}{|rccccc|}
\hline $\begin{array}{r}\text { Real } \\
\text { Variable }\end{array}$ & Notation & ADF (Constant) & p-Value & $\begin{array}{c}\text { ADF } \\
\text { (Constant, } \\
\text { Trend) }\end{array}$ & p-Value \\
\hline $\begin{array}{r}\text { Consumption } \\
\text { Real Disposable }\end{array}$ & $\ln (\mathrm{rc})$ & -1.28 & 0.64 & -2.52 & 0.32 \\
\hline $\begin{array}{r}\text { Income } \\
\text { Real Net Worth }\end{array}$ & $\ln (\mathrm{rdy})$ & -1.85 & 0.36 & -2.64 & 0.26 \\
\hline $\begin{array}{r}\text { Dependency } \\
\text { Ratio }\end{array}$ & In(dep_ratio) & -1.28 & 0.64 & -2.74 & 0.47 \\
\hline $\begin{array}{r}\text { Real Fed Funds } \\
\text { Rate }\end{array}$ & r_fed_rate & -2.39 & 0.15 & -2.37 & 0.39 \\
\hline
\end{tabular}

Given that this is the case, the next step is to test for any long-run relationships or "common trends" amongst the endogenous variables using the VAR methodology. Using the standard Johansen test, there appears to be two long-run cointegrating relationships amongst these variables (Table 2). ${ }^{10,11}$

\footnotetext{
${ }^{10}$ The Johansen (1988) test allows for a constant term in the long-run regression. We also investigate the effect of allowing for both a constant and trend term in the long-run equations in the Appendix.

${ }^{11}$ We also applied the Gregory-Hansen (1996) statistics to test the null hypothesis of no-cointegration, thereby allowing for shifts in both the constant term and time trend at an unknown break-point in the sample. The resulting $Z_{t}$ statistic of -6.49 rejects the null using a 5 percent level of significance. Evidence of cointegration was also found using their " $\mathrm{C} / \mathrm{S}$ " statistic, which allows for all the parameters of the long-run relationship including the constant term to change at an unknown break point in the sample.
} 
Table 2. Johansen Test Results

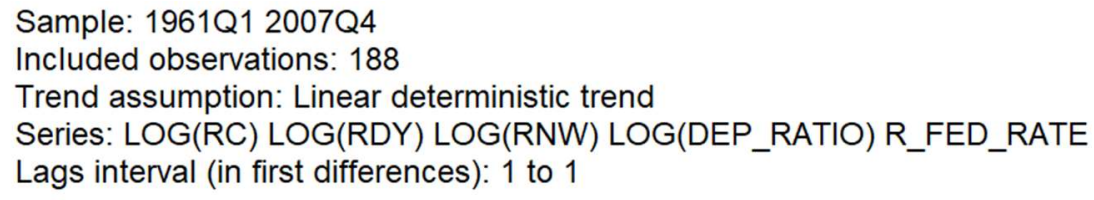

\begin{tabular}{ccccc}
\hline \hline $\begin{array}{c}\text { Hypothesized } \\
\text { No. of CE(s) }\end{array}$ & Eigenvalue & $\begin{array}{c}\text { Trace } \\
\text { Statistic }\end{array}$ & $\begin{array}{c}0.05 \\
\text { Critical Value }\end{array}$ & Prob. $^{* *}$ \\
\hline \hline None * & 0.187296 & 93.34762 & 69.81889 & 0.0002 \\
At most 1 & 0.142753 & 54.35863 & 47.85613 & 0.0108 \\
At most 2 & 0.083093 & 25.40109 & 29.79707 & 0.1476 \\
At most 3 & 0.036830 & 9.092137 & 15.49471 & 0.3569 \\
At most 4 & 0.010779 & 2.037367 & 3.841466 & 0.1535 \\
\hline
\end{tabular}

Trace test indicates 2 cointegrating eqn(s) at the 0.05 level

* denotes rejection of the hypothesis at the 0.05 level

**MacKinnon-Haug-Michelis (1999) p-values

Based on a preliminary assessment of various specifications, our prior is that the two longrun relationships are: (a) an equation explaining long-run real consumption expenditure and (b) an equation explaining the evolution of real net worth. We therefore impose sufficient identifying long-run restrictions to characterize these equations explicitly, yielding (see Table $3)$ :

$$
\begin{aligned}
& \ln \left(r c_{t}\right)=-1.04+0.95 \ln \left(r d y_{t}\right)+0.08 \ln \left(r n w_{t}\right)-0.003 r_{-} \text {fed_rate }+\varepsilon_{1 t} \\
& \ln \left(r n w_{t}\right)=13.22+1.81 \ln \left(r d y_{t}\right)-4.07 \ln \left(d e p_{-} r a t i o_{t}\right)+0.007 r_{-} \text {fed_rate } d_{t}+\varepsilon_{2 t}
\end{aligned}
$$

Two restrictions are needed to identify the long-run relationships uniquely. One restriction is that the dependency ratio affects consumption indirectly via its impact on real net worth. ${ }^{12}$ The other long-run restriction is that real consumption expenditure does not affect real net worth directly. Given these restrictions, the estimated parameters are statistically significant at the 5 percent level and of the correct sign. The variables ranked in terms of their influence on consumption (given a 1 percent shock) are: real disposable income, real net worth, the dependency ratio and, lastly, the real-interest rate. ${ }^{13}$

\footnotetext{
${ }^{12}$ Imposing a zero restriction on real Fed Fund rate instead of the dependency ratio does not change the qualitative results. The estimated parameter on the dependency ratio is insignificant in this long-run consumption relation. See appendix on identification choices.

${ }^{13}$ Net worth is the second most important variable, conditional on disposable income (which is the main driver of consumption). By borrowing on their (increasing) net wealth, households were able to increase their consumption levels beyond the average level that could be supported from income. Hence the saving rate was falling before the crisis.
} 
Table 3. Baseline VECM Model

\begin{tabular}{|c|c|c|}
\hline \multicolumn{3}{|c|}{$\begin{array}{l}\text { Sample: 1961Q1 2007Q4 } \\
\text { Included observations: } 188 \\
\text { Standard errors in ( ) \& t-statistics in [ ] }\end{array}$} \\
\hline \multicolumn{3}{|c|}{$\begin{array}{l}\text { Cointegration Restrictions: } \\
\quad \mathrm{B}(1,1)=1, \mathrm{~B}(2,1)=0, \mathrm{~B}(2,3)=1.0, \mathrm{~B}(1,4)=0, \mathrm{~A}(2,1)=0 \\
\text { Convergence achieved after } 76 \text { iterations. } \\
\text { Restrictions identify all cointegrating vectors } \\
\text { LR test for binding restrictions (rank }=2 \text { ): }\end{array}$} \\
\hline Chi-square(6) & 3.560177 & \\
\hline Probability & 0.735947 & \\
\hline Cointegrating Eq: & CointEq1 & CointEq2 \\
\hline $\operatorname{LOG}(\mathrm{RC}(-1))$ & 1.000000 & 0.000000 \\
\hline $\operatorname{LOG}(\operatorname{RDY}(-1))$ & $\begin{array}{r}-0.951039 \\
(0.02818) \\
{[-33.7481]}\end{array}$ & $\begin{array}{r}-1.814547 \\
(0.12275) \\
{[-14.7825]}\end{array}$ \\
\hline $\operatorname{LOG}(\mathrm{RNW}(-1))$ & $\begin{array}{r}-0.078551 \\
(0.02635) \\
{[-2.98050]}\end{array}$ & 1.000000 \\
\hline LOG(DEP_RATIO(-1)) & 0.000000 & $\begin{array}{r}4.074070 \\
(0.71937) \\
{[5.66340]}\end{array}$ \\
\hline R_FED_RATE(-1) & $\begin{array}{r}0.002688 \\
(0.00096) \\
{[2.78820]}\end{array}$ & $\begin{array}{r}-0.006807 \\
(0.01333) \\
{[-0.51061]}\end{array}$ \\
\hline C & 1.045430 & -13.21766 \\
\hline
\end{tabular}

We next specify the short-run model for real consumption, accounting for the fact that the variables display stochastic non-stationary behavior and are co-integrated. To do so, we use a vector error-correction model (VECM), which is specifically designed to explain the shortrun variation in real consumption around the two long-run trends. ${ }^{14} \mathrm{~A}$ VECM is a VAR in the first-difference of the same variables used in the long-run regressions, plus the lagged errorcorrection (ECM) terms.

In developing the VECM model, we include additional stationary exogenous variables to model the short-run movements in consumption: (1) a household confidence index (a forward-looking proxy for confidence, consumer sentiment); (2) the change in the unemployment rate (a proxy for income uncertainty, unemp); and (3) a proxy for financial volatility (the change in the VIX). ${ }^{15}$ The VECM also incorporates dynamics arising from

\footnotetext{
${ }^{14}$ See Johansen (1991).

${ }^{15}$ Stationarity of these variables was confirmed using the Augmented Dickey Fuller test.
} 
movements in the endogenous variables (omitted from the equation below, i.e., rdy, rnw, r_fed_rate, and dep_ratio):

$$
\begin{aligned}
& \Delta \ln \left(r c_{t}\right)=\gamma_{0}+\gamma_{1} \varepsilon_{1 t-1}+\gamma_{2} \varepsilon_{2 t-1}+\ldots+\sum_{i=0}^{p} \varphi_{i}\left(\Delta \text { unemp }_{t-i}\right)+ \\
& \sum_{j=0}^{k} \lambda_{j} \ln \left(\text { consumer_sentiment }{ }_{t-j}\right)+\sum_{l=0}^{h} \omega_{l} \Delta \ln \left(V I X_{t-l}\right)+\xi_{t}
\end{aligned}
$$

Note that a similar equation (1.4) is estimated for the other (four) endogenous variables in the system, namely rdy, rnw, dep_ratio, r_fed_rate.

The next step is to estimate equation (1.4) allowing for the additional exogenous variables (namely, $\Delta($ unemp), $\ln$ (consumer_sentiment), and $\Delta \ln (V I X)$ ), and setting the number of lags (i.e., the values of $p, k$ and $h$ ). The results are presented in Table $4 .{ }^{16}$

Considering the first equation (see column 1 of Table 4) for $\Delta \log (\mathrm{rc})$, the coefficient on its own error-correction term (i.e., CointEq1) is both negative and significant, and consistent with economic priors. Its estimated value implies that it takes around 5 quarters for a shock to consumption to dissipate (i.e., for the model to return to its long-run equilibrium). ${ }^{17}$

With respect to the equation for $\Delta \log (\mathrm{rnw})$ (see column 3), the coefficient on the errorcorrection term associated with real net worth (i.e., CointEq2) is small, suggesting weak responses of real net worth to economic shocks. The change in VIX has a significant negative effect on real net wealth (and hence consumption), but on none of the other endogenous variables directly.

The insignificance of the ECM term of net worth (CointEq2) for real consumption and disposable income points to the near weak exogeneity of real net worth - it does not respond greatly to long-run shocks in consumption. Some economists would argue that this finding is reasonable since consumption is a flow variable, while real wealth (a stock) takes more time to react to any disequilibrium in consumption relative to its long-run path.

We conducted a historical decomposition using the baseline VECM model to estimate the relative influence of the distinct structural shocks on real net worth, real disposable income and real consumption. The results for 2008-2013 are shown in Figure 4, in which the vertical bars represent the actual values of the series of interest. The importance of the variable in each period is measured by the extent to which the baseline without the structural error of

\footnotetext{
16 The number of lags (in this case, one) was determined using a Schwarz information criterion.

${ }^{17}$ Note that the VECM has six short-run restrictions imposed (see first 2 lines associated with CointEq1 and CointEq2 which are the lagged error terms in the long-run regressions). The joint test for the validity of these restrictions, which has a Chi-square distribution with 6 degrees of freedom, is 4.40 and a p-value around 0.62 (hence insignificant and the six restrictions are acceptable). The conclusion of this paper with respect to the structural break hypothesis is therefore unaffected by the imposition of these restrictions.
} 
interest (the orange line) closes the gap between the actual value of the endogenous variable (vertical bars) and the baseline forecast (blue line). It is clear from the analysis that the key drivers of real net worth and real disposable income were their own respective structural shocks, consistent with the view that the financial crisis was driven by a sequence of negative exogenous shocks (see first two rows of Figure 4). Likewise, the analysis (third row of graphs in Figure 4) suggests that these were the principal drivers of real consumption expenditure and hence the saving rate.

Table 4. VECM Parameter Estimates

\begin{tabular}{|c|c|c|c|c|c|}
\hline Error Correction: & $\mathrm{D}(\operatorname{LOG}(\mathrm{RC}))$ & $\mathrm{D}(\mathrm{LOG}(\mathrm{RDY}))$ & $\mathrm{D}(\mathrm{LOG}(\mathrm{RN} \ldots$ & $\mathrm{D}(\mathrm{LOG}(\mathrm{DE} \ldots$ & $\mathrm{D}\left(R_{-}\right.$FED_... \\
\hline CointEq1 & $\begin{array}{r}-0.194026 \\
(0.02925) \\
{[-6.63258]}\end{array}$ & $\begin{array}{c}0.000000 \\
(0.00000) \\
{[N A]}\end{array}$ & $\begin{array}{c}0.000000 \\
(0.00000) \\
{[N A]}\end{array}$ & $\begin{array}{c}0.000000 \\
(0.00000) \\
{[N A]}\end{array}$ & $\begin{array}{r}-4.898330 \\
(5.38313) \\
{[-0.90994]}\end{array}$ \\
\hline CointEq2 & $\begin{array}{c}0.000000 \\
(0.00000) \\
{[N A]}\end{array}$ & $\begin{array}{c}0.000000 \\
(0.00000) \\
{[N A]}\end{array}$ & $\begin{array}{r}-0.016427 \\
(0.00862) \\
{[-1.90572]}\end{array}$ & $\begin{array}{r}-0.000743 \\
(0.00014) \\
{[-5.17312]}\end{array}$ & $\begin{array}{c}0.000000 \\
(0.00000) \\
{[\text { [NA] }}\end{array}$ \\
\hline $\mathrm{D}(\operatorname{LOG}(\mathrm{RC}(-1)))$ & $\begin{array}{r}-0.106951 \\
(0.06857) \\
{[-1.55967]}\end{array}$ & $\begin{array}{r}0.183983 \\
(0.10841) \\
{[1.69713]}\end{array}$ & $\begin{array}{r}0.216948 \\
(0.21379) \\
{[1.01475]}\end{array}$ & $\begin{array}{c}0.004227 \\
(0.00349) \\
{[1.21060]}\end{array}$ & $\begin{array}{r}11.66696 \\
(11.6582) \\
{[1.00075]}\end{array}$ \\
\hline $\mathrm{D}(\operatorname{LOG}(\operatorname{RDY}(-1)))$ & $\begin{array}{r}0.025334 \\
(0.05255) \\
{[0.48206]}\end{array}$ & $\begin{array}{r}-0.150244 \\
(0.08308) \\
{[-1.80837]}\end{array}$ & $\begin{array}{r}-0.345801 \\
(0.16385) \\
{[-2.11050]}\end{array}$ & $\begin{array}{r}-0.004384 \\
(0.00268) \\
{[-1.63797]}\end{array}$ & $\begin{array}{r}-6.345000 \\
(8.93466) \\
{[-0.71016]}\end{array}$ \\
\hline $\mathrm{D}(\operatorname{LOG}(\mathrm{RNW}(-1)))$ & $\begin{array}{r}0.033637 \\
(0.02447) \\
{[1.37471]}\end{array}$ & $\begin{array}{c}0.038037 \\
(0.03868) \\
{[0.98329]}\end{array}$ & $\begin{array}{r}0.152441 \\
(0.07629) \\
{[1.99824]}\end{array}$ & $\begin{array}{r}0.001189 \\
(0.00125) \\
{[0.95422]}\end{array}$ & $\begin{array}{r}4.129800 \\
(4.15998) \\
{[0.99274]}\end{array}$ \\
\hline D(LOG(DEP_RATIO(-1))) & $\begin{array}{r}-0.056465 \\
(0.28859) \\
{[-0.19566]}\end{array}$ & $\begin{array}{r}-0.016962 \\
(0.45624) \\
{[-0.03718]}\end{array}$ & $\begin{array}{r}0.743941 \\
(0.89975) \\
{[0.82683]}\end{array}$ & $\begin{array}{r}0.987092 \\
(0.01470) \\
{[67.1663]}\end{array}$ & $\begin{array}{r}-40.40638 \\
(49.0636) \\
{[-0.82355]}\end{array}$ \\
\hline D(R_FED_RATE(-1)) & $\begin{array}{r}-0.000106 \\
(0.00044) \\
{[-0.24420]}\end{array}$ & $\begin{array}{r}-5.16 \mathrm{E}-05 \\
(0.00069) \\
{[-0.07501]}\end{array}$ & $\begin{array}{r}-0.001762 \\
(0.00136) \\
{[-1.29786]}\end{array}$ & $\begin{array}{r}-1.40 \mathrm{E}-05 \\
(2.2 \mathrm{E}-05) \\
{[-0.63231]}\end{array}$ & $\begin{array}{c}0.071301 \\
(0.07402) \\
{[0.96321]}\end{array}$ \\
\hline $\mathrm{C}$ & $\begin{array}{r}-0.095583 \\
(0.01938) \\
{[-4.93315]}\end{array}$ & $\begin{array}{r}-0.040576 \\
(0.03063) \\
{[-1.32463]}\end{array}$ & $\begin{array}{r}-0.168883 \\
(0.06041) \\
{[-2.79567]}\end{array}$ & $\begin{array}{r}-0.000306 \\
(0.00099) \\
{[-0.30968]}\end{array}$ & $\begin{array}{r}4.205239 \\
(3.29411) \\
{[1.27660]}\end{array}$ \\
\hline $\mathrm{D}(\mathrm{UNEMP})$ & $\begin{array}{r}-0.007148 \\
(0.00141) \\
{[-5.07885]}\end{array}$ & $\begin{array}{r}-0.003924 \\
(0.00223) \\
{[-1.76367]}\end{array}$ & $\begin{array}{r}0.003219 \\
(0.00439) \\
{[0.73366]}\end{array}$ & $\begin{array}{r}-2.25 \mathrm{E}-05 \\
(7.2 \mathrm{E}-05) \\
{[-0.31389]}\end{array}$ & $\begin{array}{r}-1.062641 \\
(0.23928) \\
{[-4.44104]}\end{array}$ \\
\hline LOG(CONSUMER_SE... & $\begin{array}{r}0.023581 \\
(0.00437) \\
{[5.39561]}\end{array}$ & $\begin{array}{r}0.010897 \\
(0.00691) \\
{[1.57713]}\end{array}$ & $\begin{array}{r}0.039728 \\
(0.01363) \\
{[2.91556]}\end{array}$ & $\begin{array}{r}6.82 E-05 \\
(0.00022) \\
{[0.30656]}\end{array}$ & $\begin{array}{r}-0.957057 \\
(0.74303) \\
{[-1.28804]}\end{array}$ \\
\hline$-D(L O G(V I X))$ & $\begin{array}{r}0.004135 \\
(0.00544) \\
{[0.75986]}\end{array}$ & $\begin{array}{r}0.003776 \\
(0.00860) \\
{[0.43894]}\end{array}$ & $\begin{array}{r}-0.060367 \\
(0.01697) \\
{[-3.55803]}\end{array}$ & $\begin{array}{r}-0.000109 \\
(0.00028) \\
{[-0.39504]}\end{array}$ & $\begin{array}{r}0.658775 \\
(0.92517) \\
{[0.71205]}\end{array}$ \\
\hline R-squared & 0.485805 & 0.164074 & 0.190540 & 0.974759 & 0.177341 \\
\hline Adj. R-squared & 0.456755 & 0.116847 & 0.144808 & 0.973333 & 0.130863 \\
\hline Sum sq. resids & 0.004332 & 0.010827 & 0.042107 & $1.12 \mathrm{E}-05$ & 125.2062 \\
\hline S.E. equation & 0.004947 & 0.007821 & 0.015424 & 0.000252 & 0.841059 \\
\hline F-statistic & 16.72277 & 3.474127 & 4.166438 & 683.5538 & 3.815585 \\
\hline Log likelihood & 736.9922 & 650.8862 & 523.2142 & 1296.745 & -228.5513 \\
\hline Akaike AIC & -7.723322 & -6.807300 & -5.449087 & -13.67814 & 2.548418 \\
\hline Schwarz SC & -7.533955 & -6.617934 & -5.259721 & -13.48878 & 2.737785 \\
\hline Mean dependent & 0.008891 & 0.008605 & 0.009333 & 0.001041 & $-8.92 \mathrm{E}-05$ \\
\hline S.D. dependent & 0.006712 & 0.008322 & 0.016679 & 0.001543 & 0.902157 \\
\hline
\end{tabular}


Figure 4. Historical Decomposition of Real Net Worth, Real Disposable Income and Real Consumption 2008Q1-2013Q4

\section{Historical Decomposition using Structural VAR Weights}
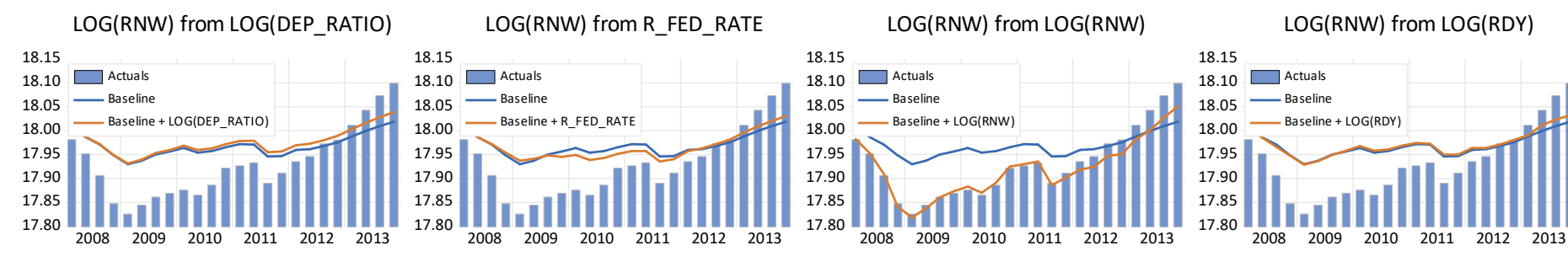

LOG(RNW) from $L O G(R C)$
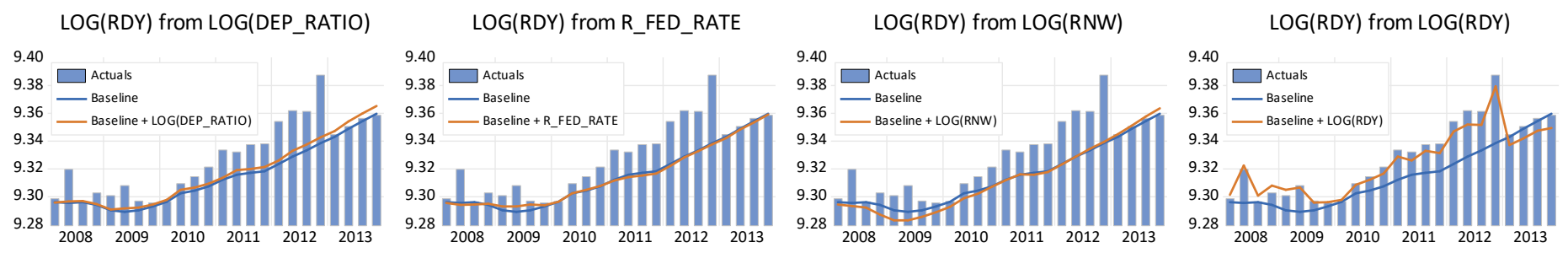

LOG(RDY) from LOG(RC)

$\begin{array}{llllll}9.28 & 2008 \quad 2009 & 2010 \quad 2011 \quad 2012 \quad 2013\end{array}$

LOG(RC) from R_FED_RATE

LOG(RC) from LOG(RNW)

LOG(RC) from LOG(RDY)

$\operatorname{LOG}(\mathrm{RC})$ from $\operatorname{LOG}(\mathrm{RC})$
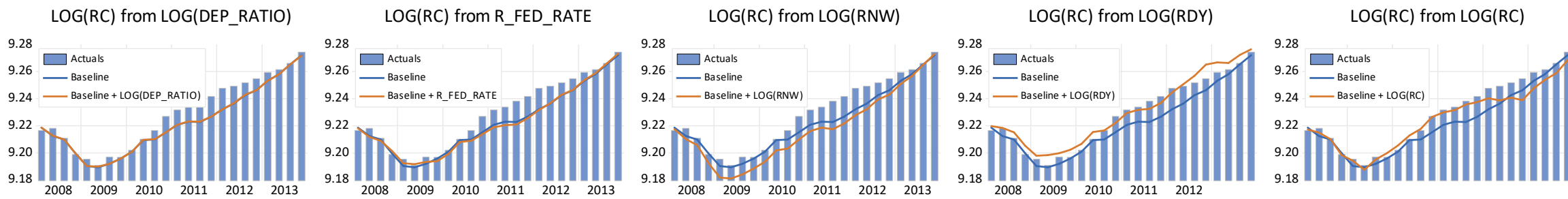
We now use the estimated VECM to produce out-of-sample predictions. The five equations in the VECM are solved simultaneously to generate the predicted path of real consumption for 2008Q1-2017Q4. We compare this path to the actual realizations of real consumption for the same period and infer from this comparison whether there has been a structural break. We use a dynamic simulation to generate the predictions, thereby allowing the prediction errors to 'build on themselves'. The dynamic prediction is calculated under the assumption that all the exogenous variables assume their actual values from 2008Q1 onwards. We map the predictions for real consumption and real income to the saving rate using equation (1.2). The resulting saving rate is shown in Figure 5 (orange line). Figure 6 (green lines) shows the predictions for the underlying endogenous variables.

Figure 5 Dynamic Simulation: Actual, Predicted and Smoothed Saving Rate, 2008Q12017Q4

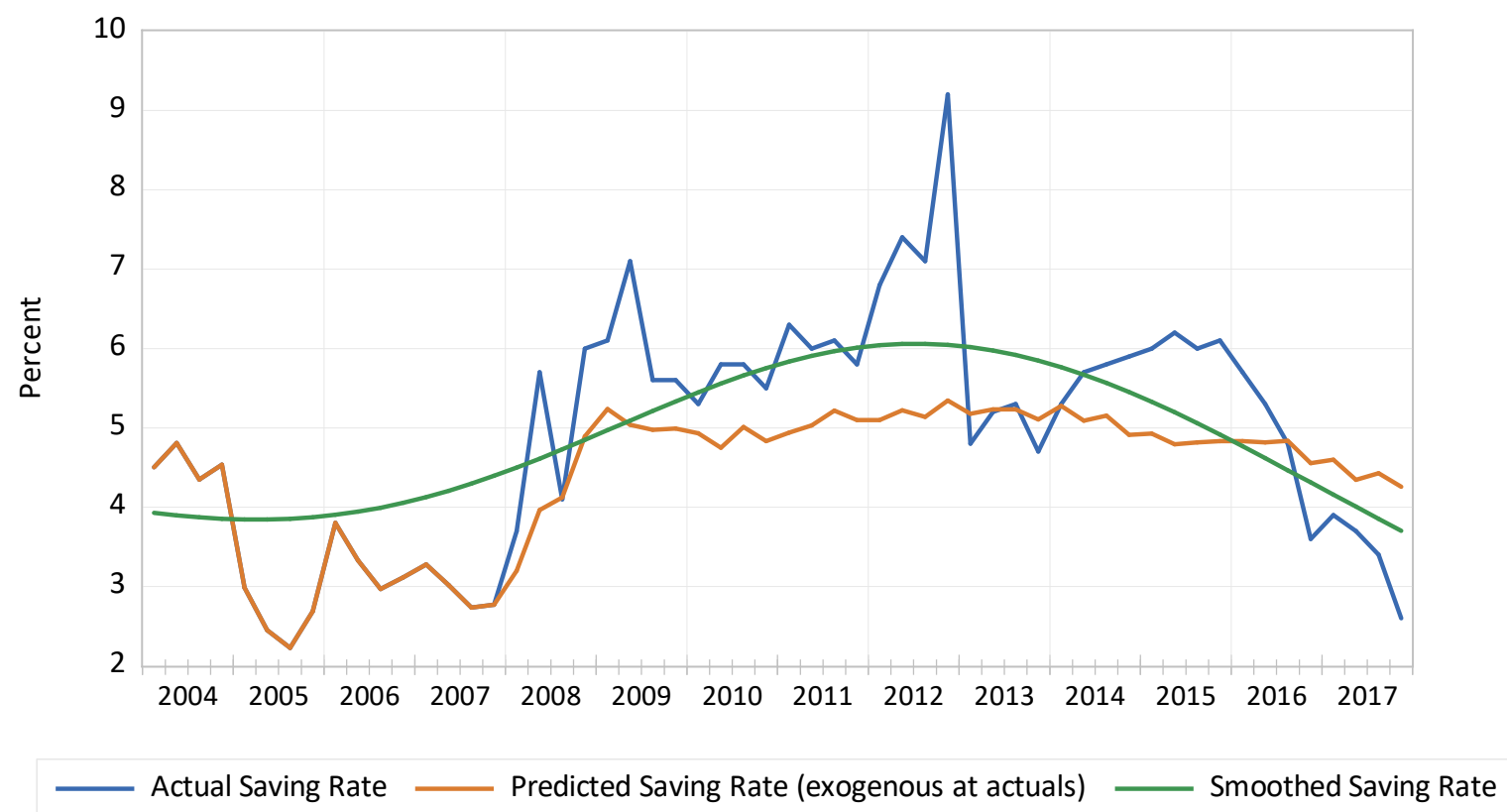

Not surprisingly, the dynamic simulation is over predicting actual real disposable income and real net wealth significantly after 2007Q4, and therefore real consumption. The positive bias reflects the unit-root characteristics of the explanatory variables, the limited serial correlation in their innovation sequences, and the fact that - prior to 2008 - both real disposable income and real net worth were trending upwards. The dynamic simulation continues the pre-crisis trends for these variables, using their last known values to generate out-of-sample predictions, thereby missing the significant negative impact of the financial crisis on disposable income and real net worth. The dynamic prediction for the saving rate (orange line, Figure 5) is systematically below the actual saving rate for much of the 2008-2016 period.

Nonetheless, we note that the empirical model used for the dynamic simulation does a reasonable job of predicting the impact of the global financial crisis on the saving rate during 2008-2009. Though the predictions are much less volatile than the actual saving rate, the model also captures the broad movements in the smoothed saving rate (i.e., the long-term 
saving rate) during 2008-2016. This is happening because the overpredictions of consumption and disposable income are similar in percentage terms, yielding reasonable predictions for the saving rate.

We can generate a confidence interval (fan chart) for the predicted saving rate by using a stochastic simulation. This involves running thousands of dynamic simulations using random (bootstrapped) shocks to the endogenous variables. Again, for this exercise it is assumed that the exogenous variables are equal to their 2007Q4 value (respectively) during 2008Q12017Q4 to calculate the simulations. The result is a (90 percent) confidence interval for the predicted saving rate, which is shown in Figure $7 .{ }^{18}$ Despite the baseline model's over prediction of real disposable income and real net worth, the dynamic fan chart encompasses the actual outcomes of the saving rate during 2008Q1-2017Q4. ${ }^{19}$ This provides some statistical evidence that the underlying model is useful for predicting the actual saving rate. Moreover, one can infer that there has not been a structural break in consumption behavior arising from the financial crisis.

Figure 6: Dynamic Predictions for the Endogenous Variables, 2008Q1-2017Q4
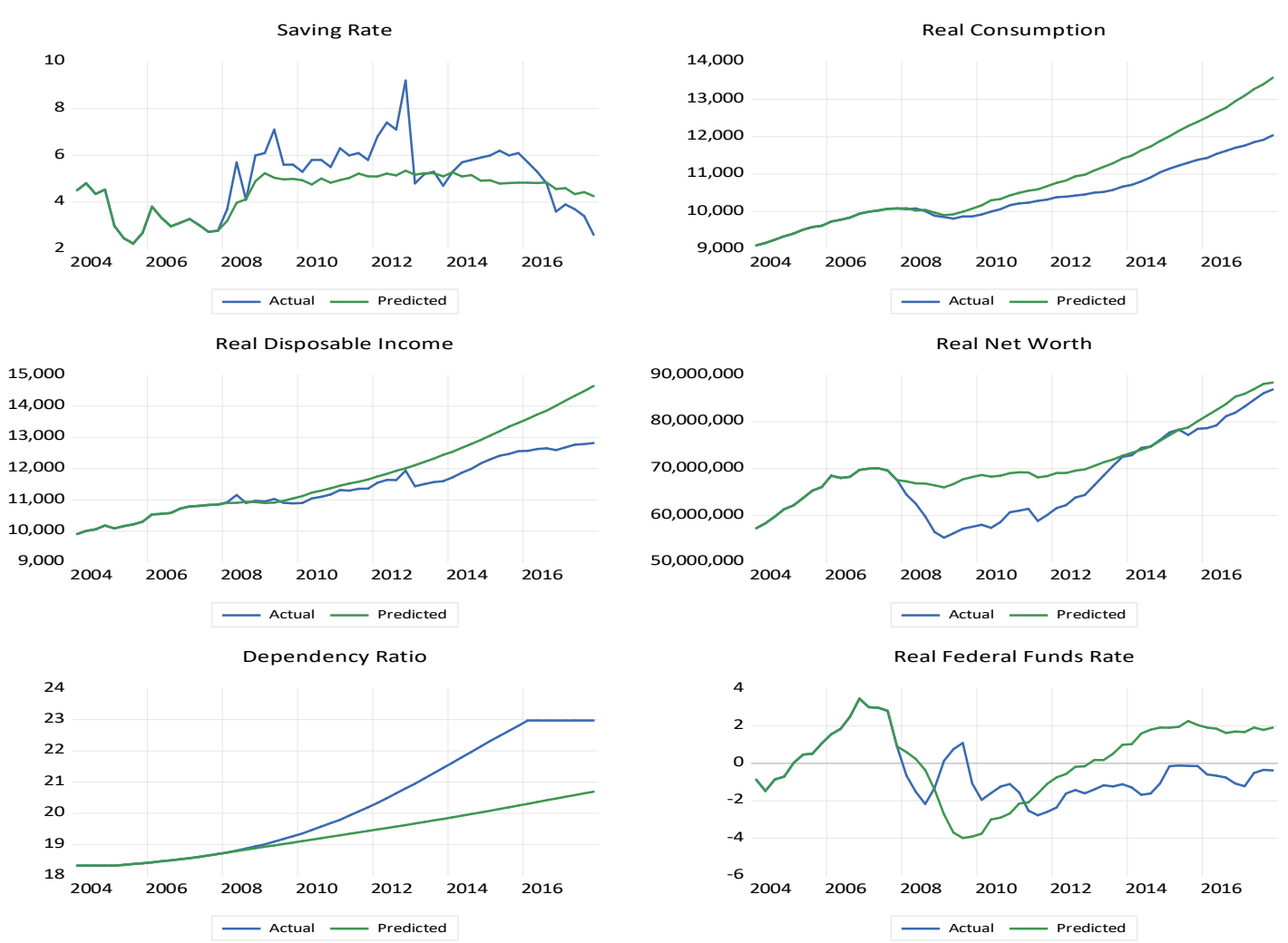

\footnotetext{
18 The fan chart allows for uncertainty in the estimated parameters of the VECM.

${ }^{19}$ A clear exception is the saving rate for 2012Q4, which occurred because of once-off lump sum social security benefit payments and accelerated dividend and bonus payments ahead of increases in tax rates scheduled for January 1, 2013.
} 
Figure 7: Saving Rate Fan Chart (Dynamic Simulation, 90 Percent Band), 2008Q1-2017Q4

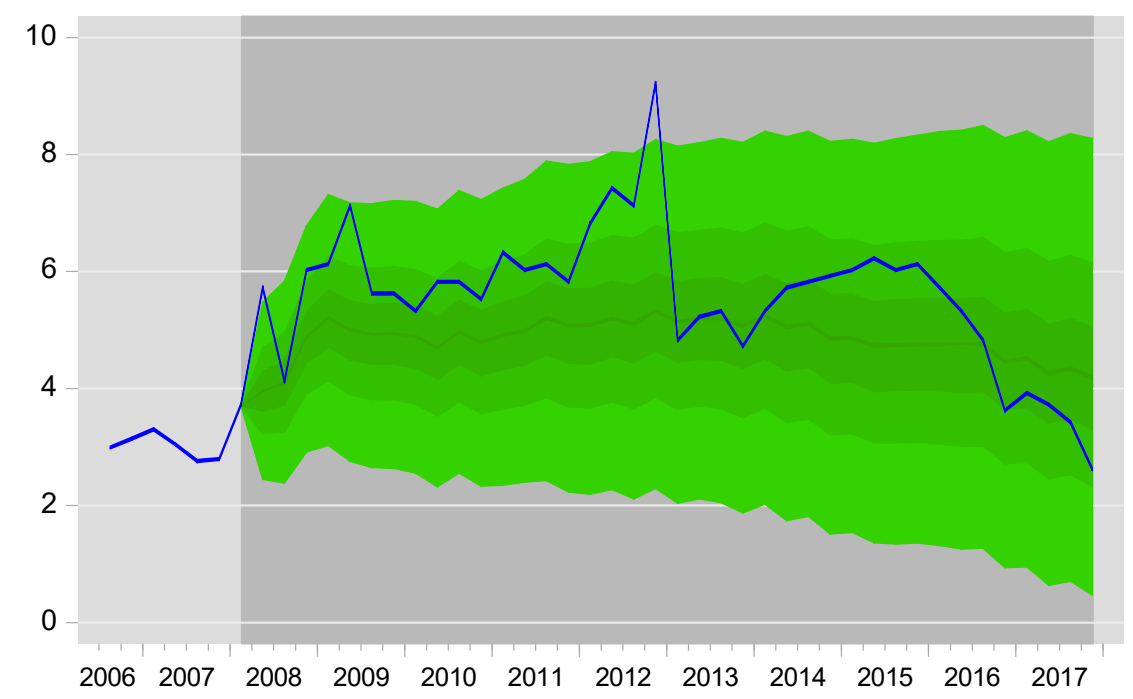

We also conducted formal tests of the structural break hypothesis using the Quandt-Andrews (1993) and Bai and Perron (2003) multi-point structural break tests applied to the recursive residuals from the VECM. ${ }^{20}$ These tests are based on standard F-statistics, and allow for unknown, multiple break points under the alternative hypothesis of a structural break. The test allows all the estimated parameters of the VECM to change as the sample size is extended one period at a time from 2008Q1 onwards to generate the recursive residuals.

The multi-point break tests are reported in Table 5 . Both statistics strongly support the null hypothesis of no structural break during 2008Q1-2017Q4. ${ }^{21}$

\footnotetext{
${ }^{20}$ The recursive residuals are the one-step ahead predictive errors from the VECM when the estimation period is extended by one period commencing 2008Q1 and ending in 2017Q4 (i.e., 40 periods). Thus, the recursive residuals are derived from 40 distinct VECM models.

${ }^{21}$ This result contrasts with that in Bianchi, Lettau, and Ludvigson (2018). They find evidence of regime shifts in the long-run relationship between consumption, labor income and household net worth. They link these shifts to low-frequency movements in the real federal funds rate. They find no evidence of regime shifts at higher frequencies (i.e., in the short-run). Their result is based on the estimation of a Markov-switching vector autoregression, which does not allow for changes in the unconditional moments of the underlying data, in contrast with the VECM approach followed in our paper.
} 
Table 5: Multiple-Point Break Tests: 2008Q1-2017Q4

\begin{tabular}{|ccc|}
\hline Statistic & Value & p-Value \\
\hline $\begin{array}{r}\text { Quandt-Andrews (1993) } \\
\text { Average Likelihood Ratio F- } \\
\text { Statistic }\end{array}$ & 0.39 & 0.74 \\
\hline $\begin{array}{c}\text { Bai - Perron (2003) Sequential 0 } \\
\text { versus 1 break F statistic }\end{array}$ & 4.72 & $>0.05$ \\
\hline \\
1 Null hypothesis is no structural break within 15 percent trimmed data. \\
Twenty-nine (29) break points were compared.
\end{tabular}

The factors behind the under-prediction of the saving rate shown in Figure 5 (green line) can be better understood by comparing the dynamic simulation to the corresponding static simulation. A static simulation resets the endogenous explanatory variables in the system to their lagged, actual values before predicting the next period's saving rate. It is more accurate than the dynamic simulation, as the forecast errors of the endogenous variables are not allowed to accumulate throughout the prediction horizon (see Figures 8 and 9). The static simulation provides further evidence on the structural break question because, if there was a permanent change in household behavior, the estimated model using data that precedes 2008Q1 would eventually produce persistent forecast errors. The fact that the predicted saving rate in Figure 8 (orange line) is near the actual saving rate throughout 2008Q12017Q4 suggests there is no structural break. Moreover, the static fan chart (Figure 10) mimics the realized volatility in the saving rate, and the confidence interval is significantly narrower than its dynamic counterpart.

Figure 8: Static Simulation: Actual, Predicted and Smoothed Saving Rate, 2008Q1-2017Q4

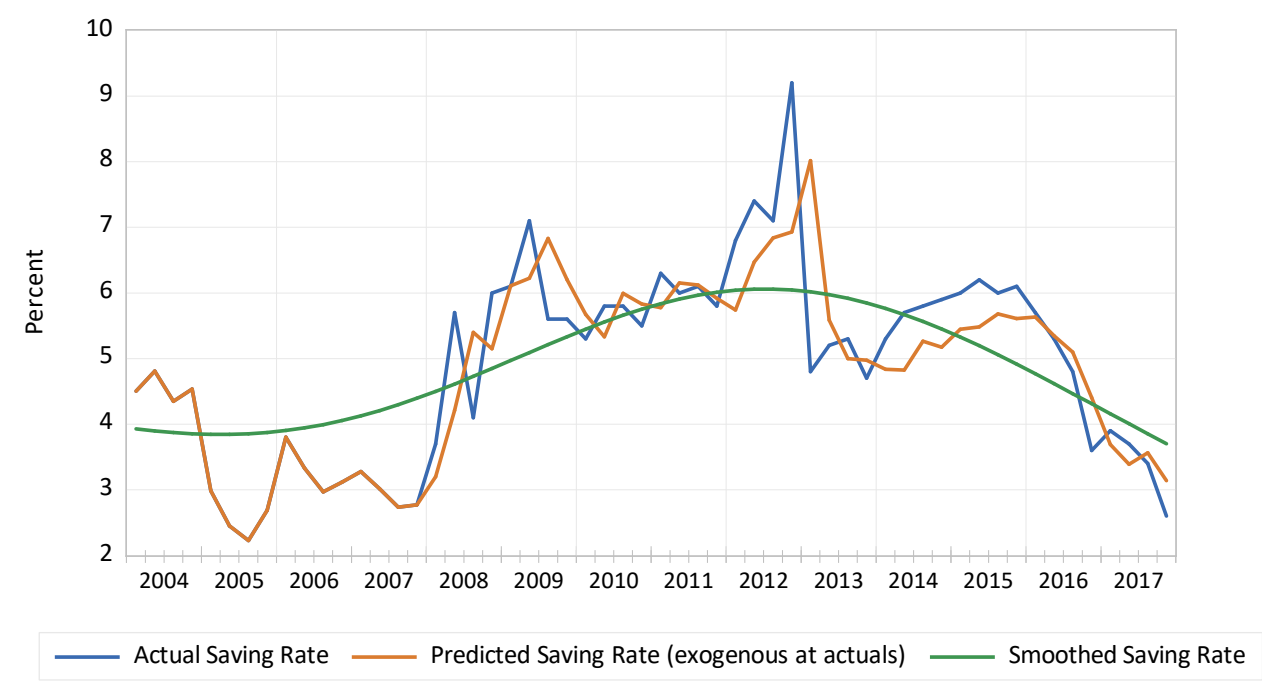


Figure 9: Static Predictions for the Endogenous Variables, 2008Q1-2017Q4
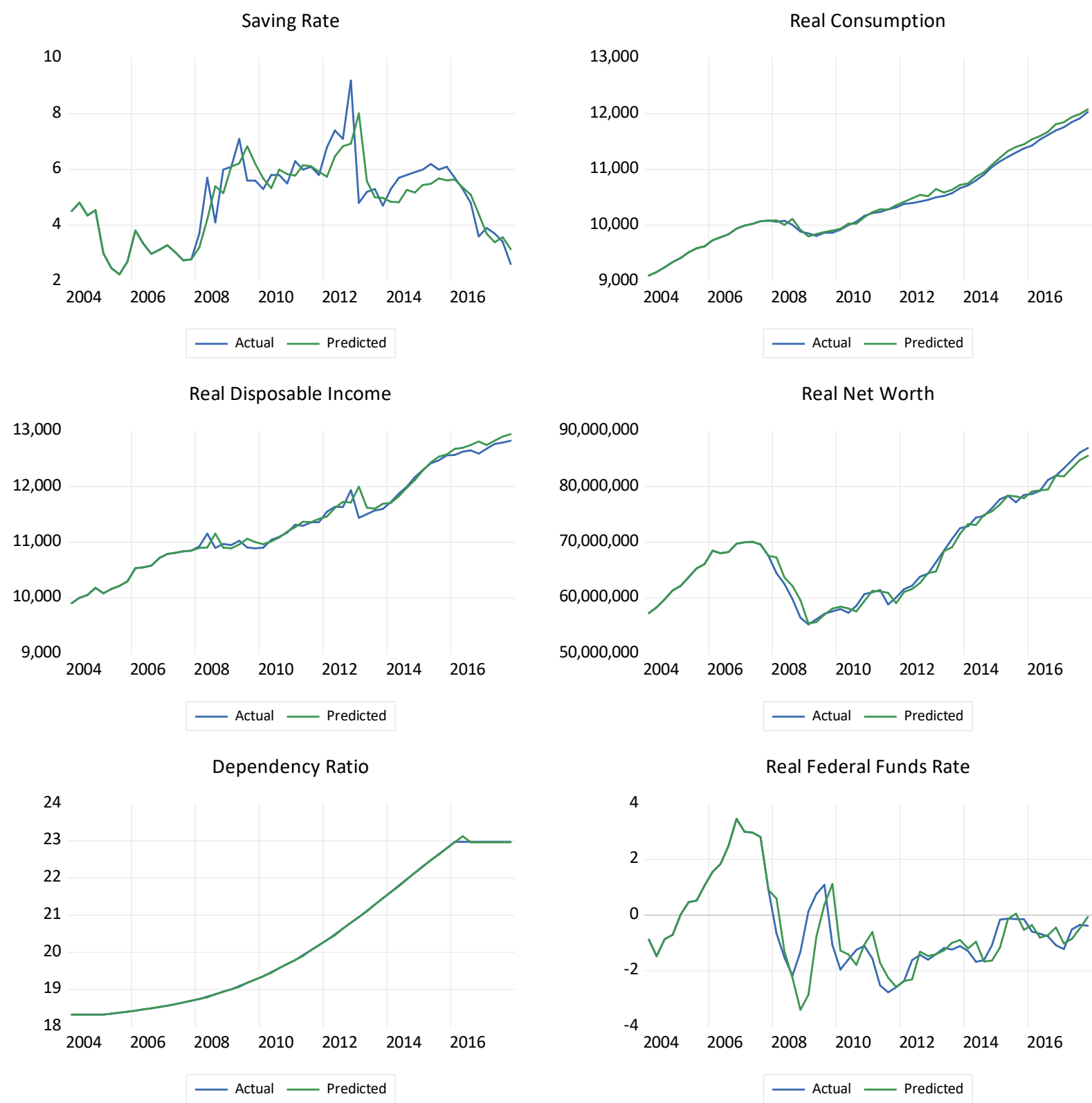

Real Federal Funds Rate

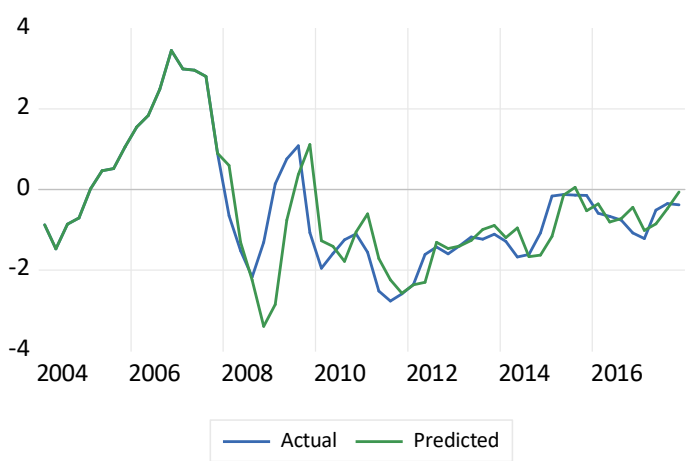


Figure 10: Saving Rate Fan Chart (Static Simulation, 90 Percent Band), 2008Q1-2017Q4

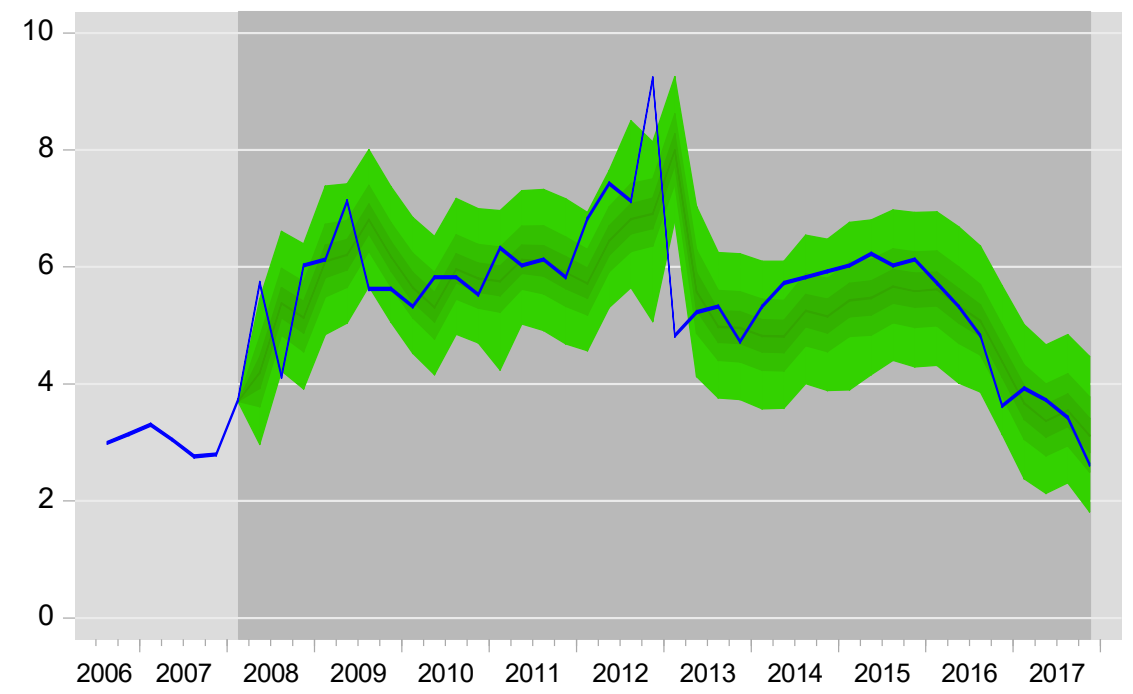

Given that we are conducting an out-of-sample simulation (i.e., we are using parameters estimated with data prior to the onset of the crisis), the superiority of the static approach implies that the dynamic simulation error in the consumption equation is largely due to the errors in predicting real disposable income, net worth, and the dependency ratio-not because of changes in the underlying parameters of the consumption function (see Figure 9). One can therefore conclude that the post-crisis behavior of the saving rate is not due to a structural/permanent change in consumption behavior. ${ }^{22}$

Table 6 ranks from highest to lowest the explanatory variables in the model according to their effect on the predicted saving rate during 2008Q1-2009Q2. ${ }^{23}$ The predicted saving rate in 2009Q2 (i.e., column 4 in Table 6) is calculated by setting each explanatory variable separately to its 2007Q4 value for 2008Q1-2009Q2 while maintaining the other explanatory variables at their actual values during the same period.

The results suggest that the main drivers of the predicted saving rate during 2008Q1-2009Q2 were real disposable income, the unemployment rate and real net worth. The large (negative) impact of higher unemployment, reflecting weaker employment prospects and higher

\footnotetext{
${ }^{22}$ Estimating the model with data from 1960 to 2001 (to avoid the 2002-2007 period, when the saving rate was unusually low) does not change the parameter estimates significantly. The predictions from the model for 2002Q1-2017Q4 are shown in the appendix. The fan charts derived from this model encompass the actual saving rate during 2002Q1-2017Q4.

${ }^{23}$ The ranking is based on the absolute change in the predicted saving rate (with respect to the 2009Q2 predicted saving rate). It is sensitive to the sample period used. We used 2007Q4-2009Q2 because the crisis began around 2008Q1 and real consumption increased consistently from 2009Q3 onwards, suggesting that the crisis was by then subsiding. Using 2009Q2 for the endpoint is also consistent with the NBER's dating of the end of the last recession (June 2009).
} 
uncertainty regarding the future amongst households, is consistent with the conclusions of Caroll (2012).

Table 6: Effect of Each Variable on the Predicted Saving Rate, 2008Q1-2009Q2

\begin{tabular}{|c|c|c|c|c|}
\hline Explanatory Variable & Rank $^{1}$ & $\begin{array}{l}\text { Actual Change } \\
(\%), 2007 Q 4- \\
2009 Q 2^{3}\end{array}$ & $\begin{array}{l}\text { Predicted } \\
\text { Saving Rate, } \\
20092^{2}\end{array}$ & $\begin{array}{l}\text { Absolute Change (\%), } \\
\text { Predicted Saving Rate, } \\
\text { 2007Q4-2009Q2 }\end{array}$ \\
\hline $\begin{array}{r}\text { Real Disposable } \\
\text { Income }\end{array}$ & 1 & 1.65 & 5.50 & 13.1 \\
\hline Unemployment & 2 & 4.5 & 6.07 & 4.04 \\
\hline Real Net Worth & 3 & -16.8 & 6.24 & 1.50 \\
\hline Consumer Sentiment & 4 & -6.2 & 6.25 & 1.30 \\
\hline Dependency Ratio & 5 & 2.11 & 6.28 & 0.75 \\
\hline VIX & 6 & -30.5 & 6.35 & 0.30 \\
\hline $\begin{array}{r}\text { Real Federal Funds } \\
\text { Rate }\end{array}$ & 7 & -0.16 & 6.34 & 0.21 \\
\hline \multicolumn{5}{|c|}{$\begin{array}{l}{ }^{1} \text { Derived by setting each variable to its } 2007 Q 4 \text { value for } 2007 Q 4-2009 Q 2 \text {; ranking is based on the absolute change in the } \\
\text { predicted saving rate. } \\
\text { 2 The predicted value for the saving rate in 2009Q2 is } 6.33 \text { percent using a static simulation and unconstrained explanatory } \\
\text { variables. The actual saving rate was } 7.1 \text { percent. }\end{array}$} \\
\hline
\end{tabular}

It follows that the higher saving rate after 2007Q4 was more a consequence of the significant negative shocks to its key drivers during the financial crisis (e.g., real net worth, real disposable income, and unemployment) rather than changes to the underlying long-run elasticities connecting real consumption to its determinants. Given the above findings, we expect the saving rate to return to its pre-2008 level once the lingering effects of the financial crisis disappear.

\section{Forecasting Performance of the Baseline Model}

We now assess the out-of-sample forecasting performance of the VECM model. Suppose the model is re-estimated using data available to 2016Q4, excluding actual data for 2017 . We then predict the saving rate during 2017Q1-2017Q4 using a static simulation to assess the model's forecasting performance. ${ }^{24}$

The first step toward calculating the prediction for the saving rate is to forecast the 2017 values for the three exogenous variables. These can be produced, for example, by using a separate forecasting model for the exogenous variables or by pooling consensus forecasts. If a separate model is used, the exogenous variables can be updated more frequently than their

\footnotetext{
${ }^{24}$ The sample was shortened to 2016Q4 to leave 4 observations for a true out-of-sample forecast assessment.
} 
native frequency (in this case, quarterly) by using higher frequency variables such as monthly industrial production and unemployment series.

Rather than using separate forecasting models, we use two different assumptions for the exogenous variables:

Assumption 1 (Blue line, Figure 11): The exogenous variables remain constant from 2017Q1 onwards: i.e., $\mathrm{X}(\mathrm{t})=\mathrm{X}(2016 \mathrm{Q} 4)$, for $\mathrm{t}=$ 2017Q1-2017Q4.

Assumption 2 (Orange line, Figure 11): The exogenous variables assume their actual values for $\mathrm{t}=2017 \mathrm{Q} 1-2017 \mathrm{Q}$.

The resulting forecasts are shown in Figure 11. In both case, the model specification produces reasonable forecasts for the actual saving rate, except perhaps for 2017Q4, when the actual saving rate was exceptionally low at 2.6 percent (its lowest value since 2005Q3). ${ }^{25}$

Figure 11: Actual and Predicted Saving Rate, 2017Q1-2017Q4

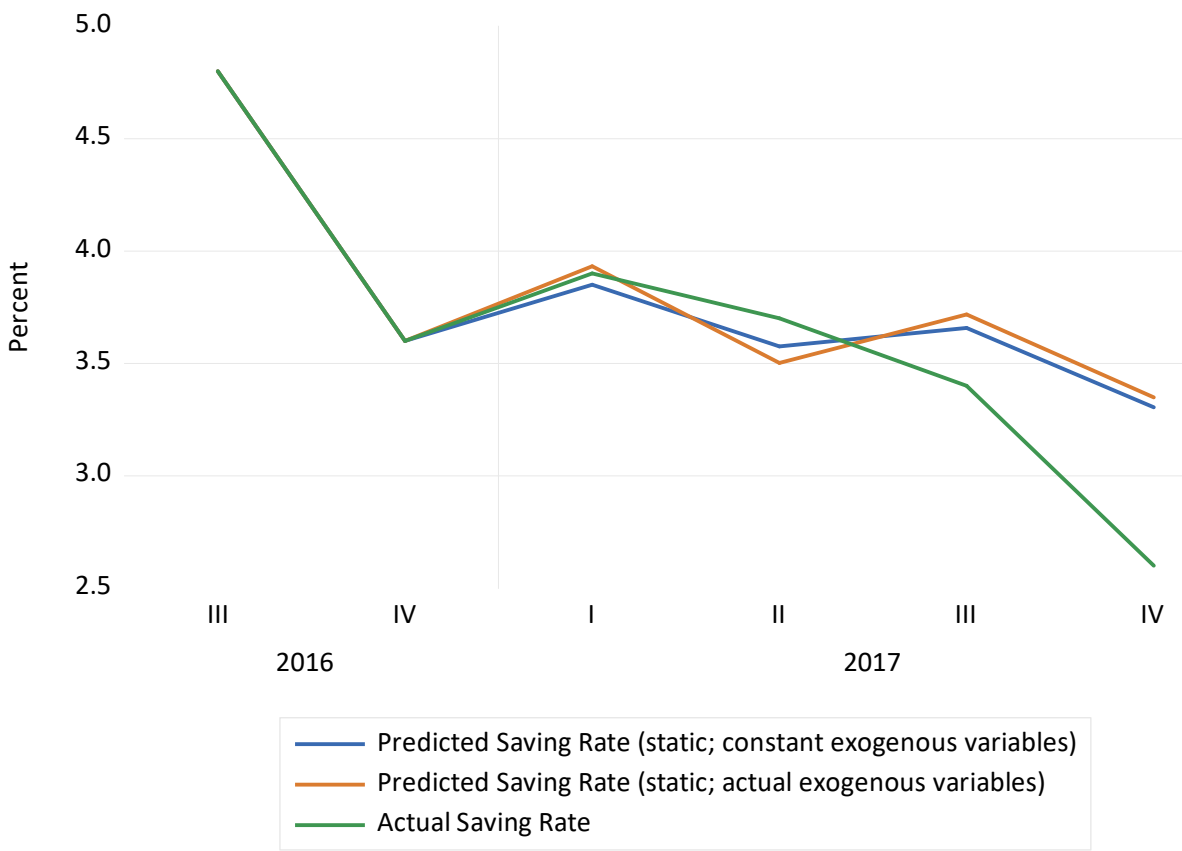

Lastly, to predict the saving rate beyond 2017Q4, we re-estimated the model using all the available data (i.e., 196Q1-2017Q4). We assumed that the exogenous variables take on their actual values until 2017Q4, but from 2017Q4 onwards, the unemployment rate is set to the IMF WEO forecast, consumer sentiment is forecast using the unemployment rate and the WEO forecasts, and the VIX is assumed to be constant.

${ }^{25}$ The median (average) saving rate for the December quarter was 5.60 (5.42) percent during 2010-2017. 
Given the mean-reverting nature of VECM models, the starting date for the dynamic projection is especially important for the predicted saving rate. If the projection starts in 2018Q1, for example, where the actual saving rate is below its long-term value (e.g., its smoothed value - see the red line in Figure 12), the dynamic projection for 2018Q1-2019Q4 will have the saving rate returning to its long-run path. In other words, since the saving rate in 2017Q4 was exceptionally low at 2.6 percent, the projected saving rate will increase toward its long-run path because of the mean-reverting nature of the VECM. The projections (orange line, Figure 12) suggest that the saving rate during 2018-2019 will increase toward 3 percent relative to its $2017 \mathrm{Q} 4$ value of 2.6 percent. ${ }^{26}$

If instead the dynamic simulation starts in 2017Q1, where the actual value for the saving rate is closer to the long-run path compared to 2017Q4, the projected saving rate declines (blue line, Figure 12) toward its long-term path, as expected.

Figure 12: Out-of-Sample Predictions for the Saving Rate: 2018Q1-2019Q4

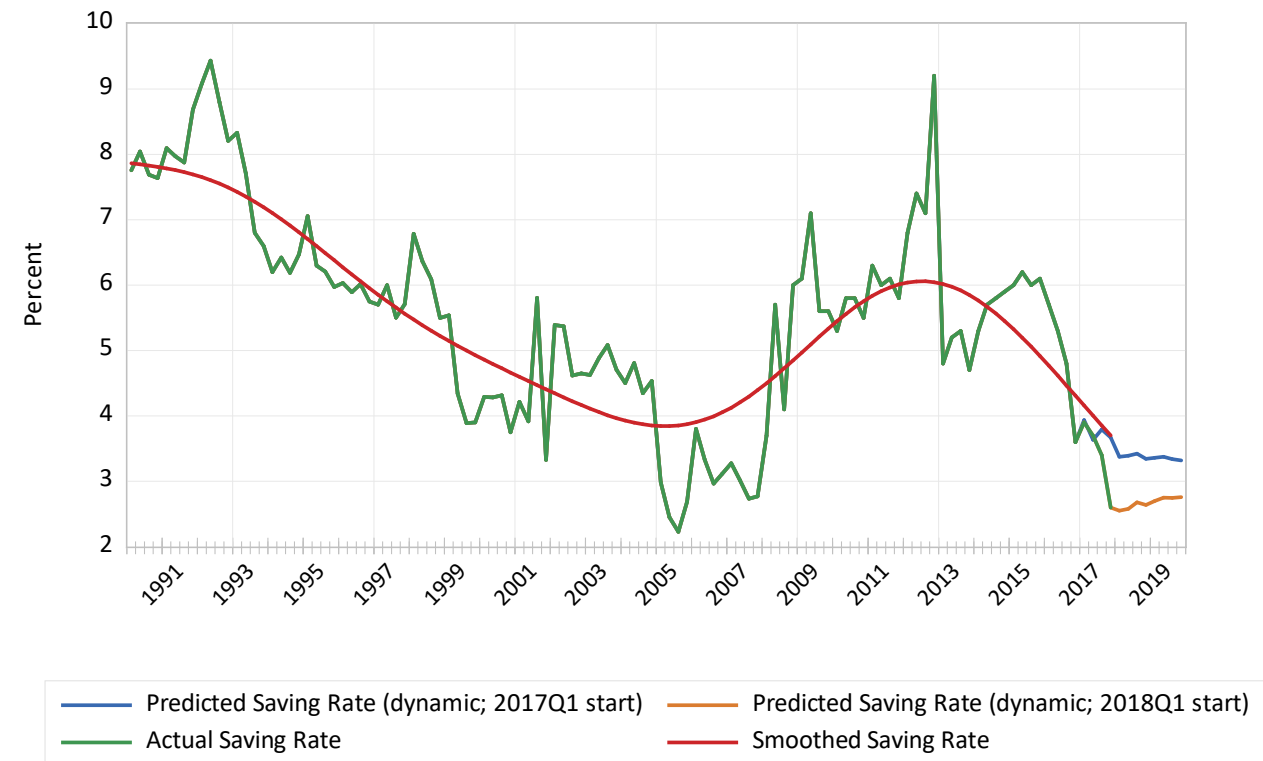

\footnotetext{
26 The latest available BEA data of 30 April 2018 indicates a saving rate of 3.1 percent for $2018 \mathrm{Q} 1$.
} 


\section{CONCLUDing REMARKS}

This study provides statistical evidence that suggests there has not been a structural change in the U.S. consumption function and saving behavior since the financial crisis. The increase in the saving rate during 2008Q1-2011Q4 can be predicted well using the (lagged, actual) values of real income and real net worth with a static simulation based on a model estimated only with data to 2007Q4. Moreover, the estimated model provides an accurate prediction of the saving rate for 2012Q1-2017Q4 providing further evidence of the absence of a structural break.

The results imply that the rise in the saving rate during 2008Q1-2011Q4 reflects the severity of the negative shocks to real net worth and unemployment during the crisis, and the weak and volatile growth in real disposable income, rather than a fundamental change in the household sectors' consumption/saving behavior. This explains why the saving rate resumed its decline in 2013, as real disposable income, employment and net worth recovered. Assuming the real growth in these determinants remain strong going forward, the results also suggest continued negative pressures on the current account deficit.

Several papers study the great depression and provide different perspectives and theories on its root causes. ${ }^{27}$ One explanation found in Romer (1990) draws on the uncertainty hypothesis which predicts that in general there should be an inverse relationship between consumer spending on durable goods and uncertainty about future income. As documented in that paper, uncertainty increased dramatically because of the stock market crash in late 1929, and the paper shows that the statistical evidence is consistent with the notion that the Great Crash depressed consumption by generating uncertainty. In our paper, we show that the effects of income and wealth uncertainty on consumer spending do appear to be the main reasons behind the change in the saving rate during the financial crisis. We showed that the change in saving patterns is not the consequence of a structural break in household behavior.

Our result also raises doubt about the secular stagnation hypothesis, since the underlying propensity to save has not increased. Indeed, Summers (2016) discusses secular stagnation, and looks into the following thought experiment: "...imagine there has been a set of forces that have pushed up the saving propensity and pushed down the investment propensity, and therefore the interest rate that has been necessary to equilibrate them has been under substantial downward pressure and that at some points they have not been equilibrated." This leads to the question: "What is it that caused saving to rise and investment to decline and therefore to create this downward pressure, this tendency toward stagnation?" Some of the explanations for this rise in savings are discussed in the paper and include rising inequality, reserve accumulation in developing countries, capital flight (notably from China), longer life expectancy, uncertainty, household deleveraging. The paper attributes the economic sluggishness to a very substantial and structural increase in saving and a decrease in investment resulting in low rates. In our paper, using as determinants of savings the real disposable income, the real net worth, the Fed funds rate, the dependency ratio and also exogenous variables such as consumer confidence, unemployment and a financial volatility

\footnotetext{
${ }^{27}$ See Friedman and Schwartz (1963), Temin (1976), Galbraith (1988), among others.
} 
index, we show that the rise in the saving function after the onset of the crisis is not the result of a structural phenomenon, but instead it is predicted to resume its declining trend, potentially going back to pre-crisis levels. Our simulation result therefore question whether the secular stagnation story was at play in the first place.

Lastly, the decline in the saving rate during 2008Q1-2011Q4 may be tied to a wealth/credit market story. Prior to 2008, households were converting their unrealized gains in the housing market into spending power (i.e., borrowing using equity backed loans). This borrowing reversed dramatically with the onset of the crisis and the subsequent need to restructure/deleverage balance sheets. As real income and especially net worth recover, households can revert to their previous consumption norms, leading to a reduction in the personal saving rate. Indeed, conditional on income, the recent increases in net worth are likely to encourage households to borrow to finance further consumption, which would lead to a reduction in the personal saving rate. 


\section{REFERENCES}

Ando, Albert, and Franco Modigliani, 1963, “The 'Life-Cycle' Hypothesis of Saving: Aggregate Implications and Tests,” American Economic Review, Vol. 53, No. 1, pp. $55-84$.

Andrews, Donald W. K., 1993, "Tests for Parameter Instability and Structural Change with Unknown Change Point," Econometrica, Vol. 61, No. 4. pp. 821-856.

Bai, Jushan and Pierre Perron, 2003, "Computation and Analysis of Multiple Structural Change Models," Journal of Applied Econometrics, Vol. 18, pp. 1-22.

Bianchi, Francesco, Mark Lettau and Sydney C. Ludvigson, 2018, "Monetary Policy and Asset Valuation," unpublished working paper, https://www.sydneyludvigson.com/s/reg.pdf

Cagetti, Marco, 2003, "Wealth Accumulation over the Life Cycle and Precautionary Savings," Journal of Business and Economic Statistics, Vol. 21 (July), pp. 339-53.

Carroll, Christopher D., 1997, "Buffer-Stock Saving and the Life Cycle/Permanent Income Hypothesis," Quarterly Journal of Economics, Vol. 112, No. 1, pp. 1-55.

Carroll, C., J. Slacalek, and M. Sommer, 2012, "Dissecting Saving Dynamics: Measuring Wealth, Precautionary and Credit Effects,” ECB Working Paper Series No 1474.

Corbae, Dean, Ouliaris, Sam and Phillips, Peter C B, 1994, "A Reexamination of the Consumption Function Using Frequency Domain Regressions," Empirical Economics, Springer, Vol. 19(4), pp. 595-609.

Epstein, Larry G. and Stanley Zin, 1991, "Substitution, Risk Aversion, and the Temporal Behavior of Consumption and Asset Returns: An Empirical Analysis Preview," Journal of Political Economy, Vol. 99, issue 2 (April), pp. 263-86.

Friedman, Milton, and Anna J. Schwartz, A Monetary History of the United States, 1867-1960 (Princeton, NJ: Princeton University Press for NBER, 1963).

Galbraith, John Kenneth, The Great Crash 1929 (Boston: Houghton Mifflin, 1988).

Gourinchas, Pierre-Olivier, and Jonathan Parker, 2002, "Consumption over the Life-Cycle," Econometrica, Vol. 70, No. 1, pp. 47-89.

Gregory, Alan and Bruce Hansen, 1996 "Residual-Based Tests for Cointegration in Models with Regime Shifts," Journal of Econometrics, Vol. 70, pp. 99-126.

Johansen, Soren, 1988, "Statistical analysis of cointegration vectors," Journal of Economic Dynamics and Control, Vol. 12(2-3), pp. 231-54. 
, 1991, "Estimation and Hypothesis Testing of Cointegrating Vectors in Gaussian Vector Autoregressive Models," Econometrica 59, pp. 1551-80.

Lee, Jaewoo, Pau Rabanal and Damiano Sandri, 2010, “U.S. Consumption after the 2008 Crisis," IMF Working Paper.

Lettau, Mark and Sydney Ludvigson, 2004, "Understanding Trend and Cycle in Asset Values: Reevaluating the Wealth Effect on Consumption," American Economic Review, Vol. 94, 1 (March), pp. 276-99.

Maki, Dean M., and Michael G. Palumbo, 2001, "Disentangling the Wealth Effects: A Cohort Analysis of Household Saving in the 1990s," Finance and Economics Discussion Series 2001-21 (Washington: Board of Governors of the Federal Reserve System).

Romer, Christina D., 1990, “The Great Crash and the Onset of the Great Depression," Quarterly Journal of Economics, Vol. 105 (August), pp. 597-624.

Summers, Lawrence (2016), "Secular Stagnation and Monetary Policy”, Federal Reserve Bank of St. Louis Review, Second Quarter 2016, 98(2), pp. 93-110. http://dx.doi.org/10.20955/r.2016.93$\underline{110}$

Temin, Peter, Did Monetary Forces Cause the Great Depression? (New York: W. W. Norton, 1976). 
APPENDIX

\section{Allowing for a Trend in the Long-Run Model}

Adding a trend term to the long-run equation for real consumption does not affect the number of long-run relationships in the model. However, the augmented model is harder to motivate from an economic perspective since it presumes that the growth rate of the endogenous variables in the system can be influenced by a linear trend. Moreover, the significance of net worth on consumption disappears when a trend is included in the estimated VECM, suggesting it is acting as an instrument for this important determinant of consumption.

Adding a trend term to the VECM (via the long-run relationship) introduces negative bias in the dynamic predictions for the saving rate compared to the model without a trend (see Figure 13, green versus orange line). This reflects the impact of the positive coefficient on the trend term in the long-run consumption equation, which lowers the saving rate at each point in the forecast horizon. The corresponding dynamic and static fan charts, however, still encompass the actual values of the saving rate during 2008Q1-2017Q4, suggesting no structural break in the estimated equations (Figure 14). Lastly, the null hypothesis of no structural break is supported by the Quandt-Andrews and Bai-Perron statistics applied to the recursive residuals from the trend-augmented VECM (Table 7).

Figure 13: Predictions with a Trend term in the Long-Run Model, 2008Q1-2017Q4

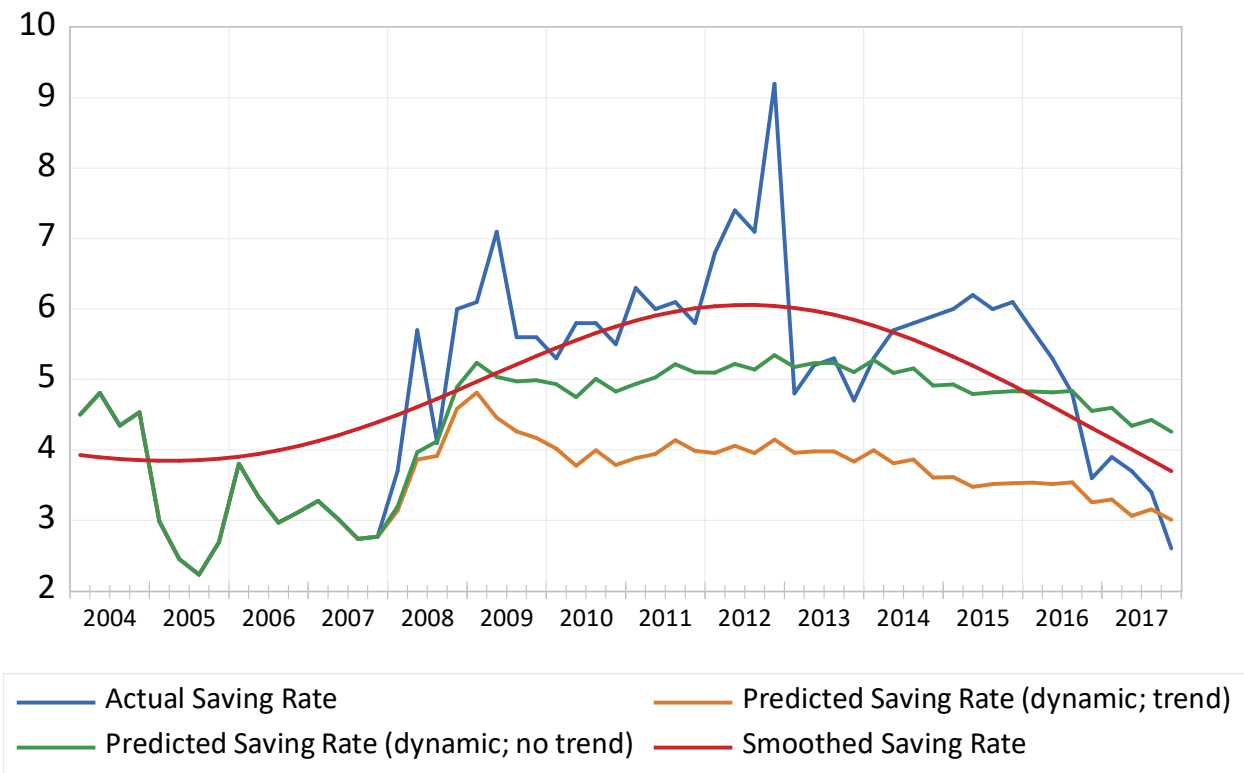


Figure 14: Fan Charts for the Saving Rate with Trend, 2008Q1-2017Q4
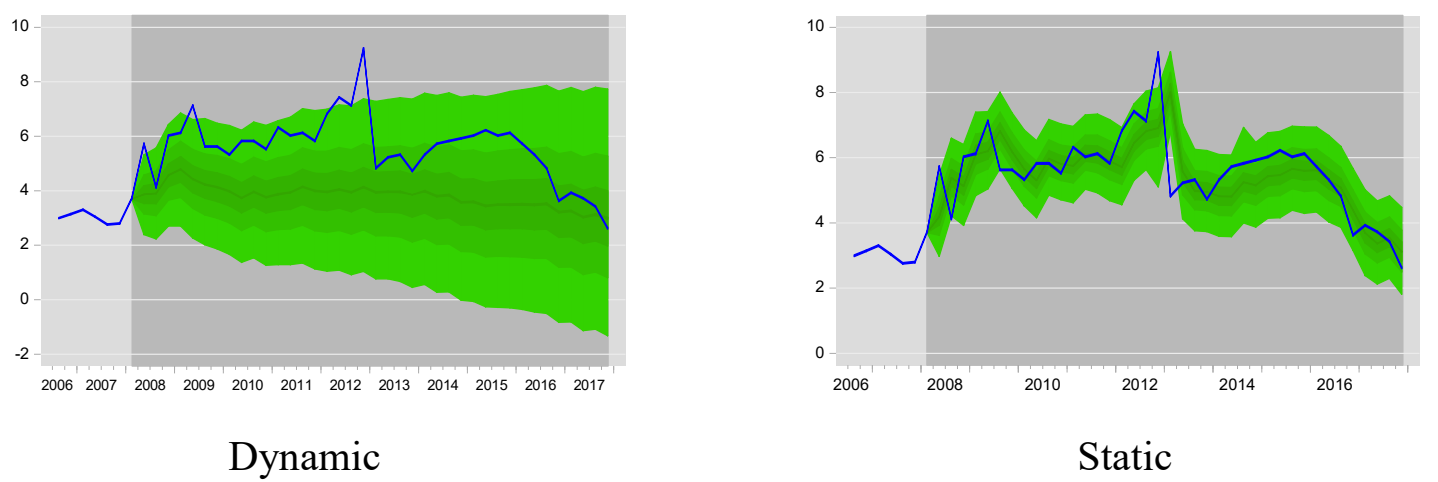

Table 7: Multiple-Point Break Tests: Trend, 2008Q1-2017Q4

\begin{tabular}{|rcc|}
\hline Statistic $^{1}$ & Value & p-Value \\
\hline $\begin{array}{r}\text { Quandt-Andrews (1993) } \\
\text { Average Likelihood Ratio F- } \\
\text { Statistic }\end{array}$ & 0.39 & 0.74 \\
$\begin{array}{r}\text { Bai - Perron (2003) Sequential 0 } \\
\text { versus 1 break F statistic }\end{array}$ & 4.72 & $>0.05$ \\
\hline
\end{tabular}

${ }^{1}$ Null hypothesis is no structural break within 15 percent trimmed data.

Twenty-nine (29) break points were compared.

\section{Choice of Estimation Period}

One may ask whether the low saving rate during 2002-2007 is the main reason for the finding of no structural break. To assess this issue, we narrowed the estimation period to 1961Q12001Q4 and recalculated the projections. The results are shown in Figures 15 and 16, and formal tests of the structural break hypothesis are presented in Table 8 . The predictions assume that the exogenous variables (unemployment, consumer sentiment, and VIX) assume their actual values after 2001Q4. Given that the fan charts for this model encompass the actual saving rate during 2002Q1-2017Q4, and the multi-period structural break tests are both insignificant, our finding of no structural break is not sensitive to the use of 1961Q12007Q4 data to estimate the model. 
Figure 15: Dynamic Predictions, Shorter Sample, 2002Q1-2017Q4

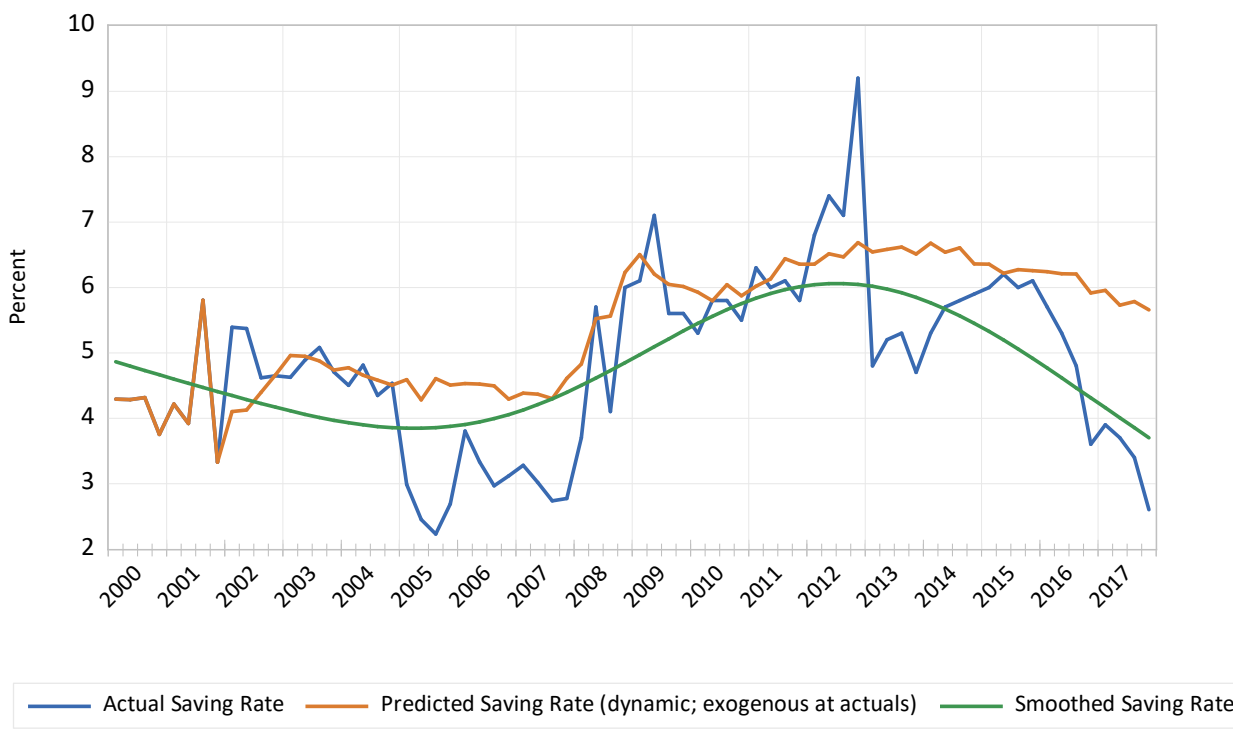

Figure 16: Fan Charts for the Saving Rate: 2002Q1-2017Q4

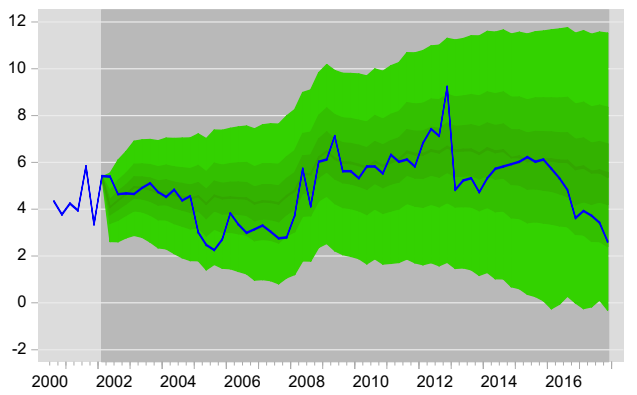

Dynamic

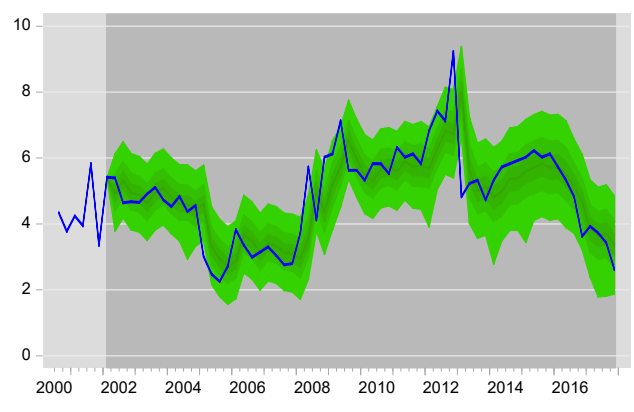

Static

Table 8: Multiple-Point Break Tests: Shorter Sample, 2002Q1-2017Q4

\begin{tabular}{|rcc|}
\hline Statistic $^{1}$ & Value & p-Value \\
\hline $\begin{array}{r}\text { Quandt-Andrews (1993) } \\
\text { Average Likelihood Ratio F- } \\
\text { Statistic }\end{array}$ & 0.82 & 0.42 \\
\hline $\begin{array}{r}\text { Bai - Perron (2003) Sequential 0 } \\
\text { versus 1 break F statistic }\end{array}$ & 1.61 & $>0.05$ \\
\hline
\end{tabular}

1 Null hypothesis is no structural break within 15 percent trimmed data. Fortyfive (45) break points were compared. 


\section{Identification Choices}

The preferred model imposes the restriction that the dependency ratio does not affect real consumption expenditure directly, but rather indirectly via real net worth. We now repeat the analysis with a zero restriction on the real federal funds rate rather than the dependency ratio.

Under this new identification scheme, the dynamic prediction for the saving rate during 2008Q1-2017Q4 captures the overall trend in the actual saving rate (Figure 17). Moreover, the dynamic and static fan charts continue to include the actual values of the saving rate for 2008Q1-2017Q4 (Figure 18), and the multiple-point structural break tests support the null hypothesis of no structural break (Table 9).

Figure 17: Dynamic Prediction: Alternative Identification, 2008Q1-2017Q4

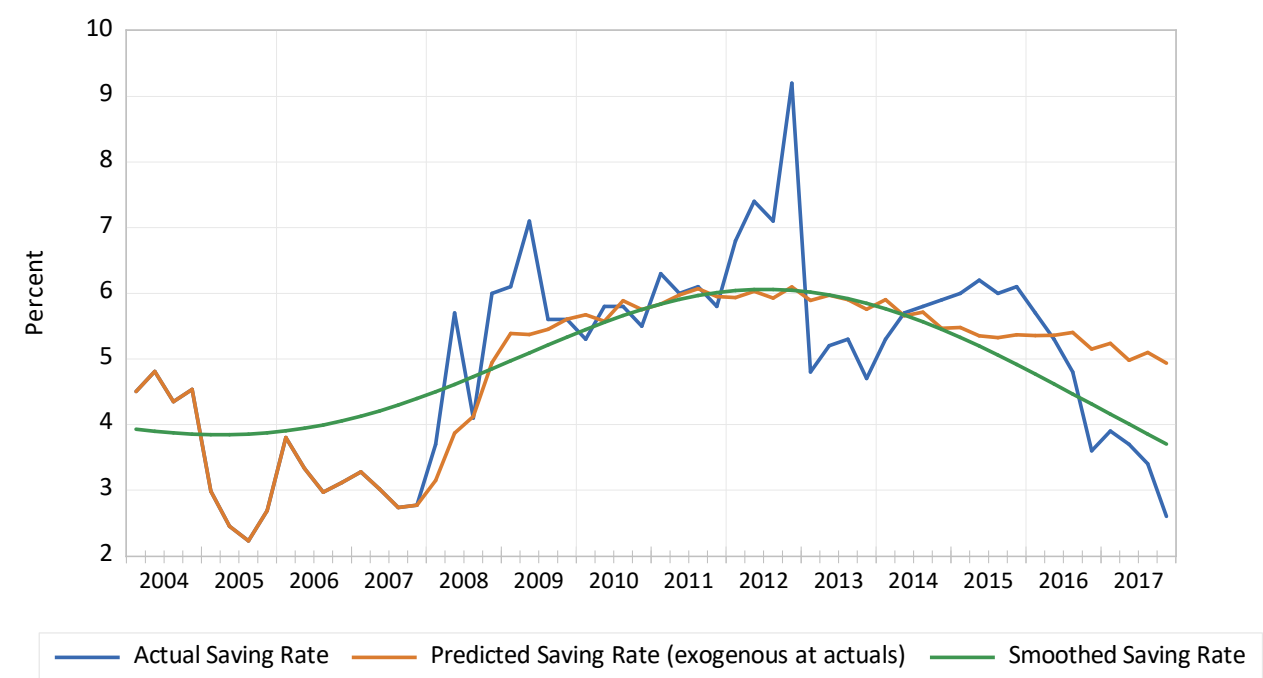

Figure 18: Fan Charts for the Saving Rate: Alternative Identification

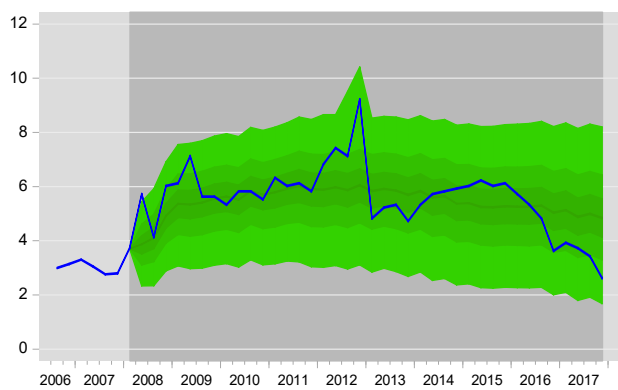

Dynamic

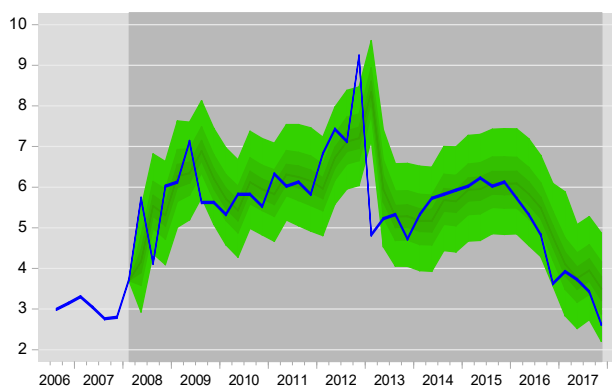

Static 
Table 9: Multiple-Point Break Tests: Alternative Identification, 2008Q1-2017Q4

\begin{tabular}{|rcc|}
\hline Statistic $^{1}$ & Value & p-Value \\
\hline $\begin{array}{r}\text { Quandt-Andrews (1993) } \\
\text { Average Likelihood Ratio F- } \\
\text { Statistic }\end{array}$ & 1.24 & 0.25 \\
\hline $\begin{array}{r}\text { Bai - Perron (2003) Sequential 0 } \\
\text { versus 1 break F statistic }\end{array}$ & 4.21 & $>0.05$ \\
\hline
\end{tabular}

${ }^{1}$ Null hypothesis is no structural break within 15 percent trimmed data.

Twenty-nine (29) break points were compared. 